\title{
Pangea B and the Late Paleozoic Ice Age
}

\author{
D.V. Kent ${ }^{\mathrm{a}, \mathrm{b}, *}, \mathrm{G}$. Muttoni $^{\mathrm{c}}$ \\ ${ }^{\text {a }}$ Earth and Planetary Sciences, Rutgers University, Piscataway, NJ 08854, USA \\ b Lamont-Doherty Earth Observatory of Columbia University, Palisades, NY 10964, USA

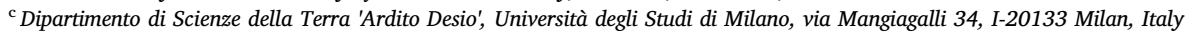

\section{A R T I C L E I N F O}

Editor: Thomas Algeo

Keywords:

Late Paleozoic Ice Age

Pangea A

Pangea B

Greater Variscan orogen

Equatorial humid belt

Silicate weathering $\mathrm{CO} 2$ consumption

Organic carbon burial

\begin{abstract}
A B S T R A C T
The Late Paleozoic Ice Age (LPIA) was the penultimate major glaciation of the Phanerozoic. Published compilations indicate it occurred in two main phases, one centered in the Late Carboniferous ( $~ 315 \mathrm{Ma})$ and the other in the Early Permian ( $\sim 295 \mathrm{Ma}$ ), before waning over the rest of the Early Permian and into the Middle Permian ( $\sim 290 \mathrm{Ma}$ to $275 \mathrm{Ma})$, and culminating with the final demise of Alpine-style ice sheets in eastern Australia in the Late Permian ( $\sim 260$ to $255 \mathrm{Ma}$ ). Recent global climate modeling has drawn attention to silicate weathering $\mathrm{CO}_{2}$ consumption of an initially high Greater Variscan edifice residing within a static Pangea A configuration as the leading cause of reduction of atmospheric $\mathrm{CO}_{2}$ concentrations below glaciation thresholds. Here we show that the best available and least-biased paleomagnetic reference poles place the collision between Laurasia and Gondwana that produced the Greater Variscan orogen in a more dynamic position within a Pangea B configuration that had about $30 \%$ more continental area in the prime equatorial humid belt for weathering and which drifted northward into the tropical arid belt as it transformed to Pangea A by the Late Permian. The presence of widespread equatorial coal basins with Euramerica flora in the footprint of the Greater Variscan orogen during the Late Carboniferous is more compatible with a heterogeneous horst-and-graben morphology, characterized by uplifted crystalline massifs acting as loci of intense silicate weathering $\mathrm{CO}_{2}$ consumption and supplying sediment for proximal basins as venues of organic carbon burial, than a contiguous high mountain plateau, as assumed in recent climate modeling of the LPIA and its demise. The culminating phase of the LPIA occurred at about $275 \mathrm{Ma}$ with the transformation from Pangea B to Pangea A and the attendant reduction of continental area in the equatorial humid belt, as well as with continued northward drift that placed what remained of the Greater Variscan orogen into the Zechstein arid belt in the Late Permian, by which time the geologic landscape was largely blanketed with siliciclastics. The resulting warming from reduced silicate weathering and thus increasing $\mathrm{pCO}_{2}$ was interrupted at $260 \mathrm{Ma}$ with a cooling trend that coincided with emplacement of the Emeishan large igneous province on the equatorial South China Craton as well as the drift of the Cimmerian continental blocks through the equatorial humid belt due to opening of the Neo-Tethys. A return to ice age conditions from the increase in silicate weathering uptake of $\mathrm{CO}_{2}$ was avoided by drift of the Emeishan large igneous province out of the equatorial belt, that in conjunction with massive outgassing from emplacement of the Siberian Traps in high latitudes at the end of the Permian (252 Ma), helped steer the climate system to sustained non-glacial conditions.
\end{abstract}

\section{Introduction}

Gondwanan glaciations (Du Toit, 1937) constituting the Late Paleozoic Ice Age (LPIA) from $\sim 330 \mathrm{Ma}$ to $\sim 255 \mathrm{Ma}$ in the Carboniferous-Permian (Fielding et al., 2008b; Montañez and Poulsen, 2013) were the last major glacial episode preceding the current Late Cenozoic Ice Age that started at $\sim 34 \mathrm{Ma}$ in the Paleogene (e.g., Zachos et al., 1992). From some of the earliest climate modeling of the LPIA (Crowley and Baum, 1992; Crowley et al., 1991), its atypical cold climate was attributed to sustained low $p \mathrm{CO}_{2}$ (exacerbated by $\sim 3 \%$ lower solar luminosity that is part of a long-term trend) with land-sea distributions of the Gondwana supercontinent apparently having only subsidiary effects (Crowley and Berner, 2001). This is the $\mathrm{CO}_{2}$ paradigm, postulating that long-term climate variations are fundamentally driven by varying concentrations of atmospheric carbon dioxide $\left(p \mathrm{CO}_{2}\right)$ (Berner, 1990; Donnadieu et al., 2006), which ultimately vary as the net result of planetary outgassing and $\mathrm{CO}_{2}$ consumption from weathering of continental silicates and burial of organic carbon (Berner, 1990; Berner et al., 1983; Walker et al., 1981). Sensitivity studies with global climate modeling that include solar luminosity and continental drift confirm

\footnotetext{
* Corresponding author at: Lamont-Doherty Earth Observatory of Columbia University, Palisades, NY 10964, USA.

E-mail addresses: dvk@1deo.columbia.edu (D.V. Kent), giovanni.muttoni1@unimi.it (G. Muttoni).
} 
that $p \mathrm{CO}_{2}$ change was the likely primary control on Late Paleozoic glaciation (Lowry et al., 2014).

Variable $\mathrm{CO}_{2}$ outgassing using ocean floor production as a proxy is the underlying driver of the GEOCARB family of carbon cycling models (e.g., Berner et al., 1983; Berner, 1994; Li and Elderfield, 2013). The lower $p \mathrm{CO}_{2}$ required to explain the LPIA was thus attributed to reduced ocean floor production, which in the absence of contemporaneous ocean floor was inferred from sequence stratigraphy (Vail et al., 1977) and a presumed ridge volume dependence from seafloor generation (Gaffin, 1987; Berner, 1990). However, over the past 180 Myr when direct seafloor estimates are possible, the areal distribution of seafloor ages is not inconsistent with that expected from steady long-term ocean floor production (Rowley, 2002), a result confirmed within $\pm 20 \%$ variation about a constant mean by Cogné and Humler (2004) who moreover found no clear correlation of the variations with changes in sea level. Given the determinative importance yet inherent uncertainty of any specific spreading-related outgassing function, especially for the Late Paleozoic, we assume the null hypothesis that $\mathrm{CO}_{2}$ volcanic outgassing was steady at about the modern level $\left(\sim 260 \mathrm{Mt} \mathrm{CO}_{2} / \mathrm{yr}\right.$ or $6 \times 10^{12} \mathrm{~mol} \mathrm{CO}_{2} /$ yr: Marty and Tolstikhin, 1998; Gerlach, 2011).

The assumption of steady $\mathrm{CO}_{2}$ outgassing means that variations in carbon sinks from silicate weathering and organic carbon burial need to be sought to account for the effects of varying $p \mathrm{CO}_{2}$ concentrations on global climate on geologic time scales. $\mathrm{CO}_{2}$ consumption has often been described in terms of weatherability (Francois and Walker, 1992), the product of various factors that can affect chemical erosion of continents including lithology, relief, glaciation and plant coverage (Kump and Arthur, 1997). However, the weathering of $\mathrm{CaO}$ and $\mathrm{MgO}$-rich mafic crystalline rocks is clearly of the utmost importance for the global carbon cycle and climate regulation; for example, $\mathrm{CO}_{2}$ consumed by chemical weathering of basalts exposed in volcanic arcs, oceanic islands, and large igneous provinces today is estimated to constitute $>30 \%$ of continental $\mathrm{CO}_{2}$ consumption (Gaillardet et al., 1999; Dessert et al., 2003). Of course, the basalts need to be exposed (weatheringlimited rather than transport-limited; Stallard and Edmond, 1983) to realize their $\mathrm{CO}_{2}$ consumption potential, which requires topographic relief from tectonic uplift and exhumation as generally occur in arccontinent or continent-continent collision orogens. Finally, chemical weathering $\mathrm{CO}_{2}$ consumption of such epimafic rocks will depend on the availability of water especially under warm temperatures, environmental conditions optimally associated with the equatorial humid belt. We thus regard weatherability as simply the maximum potential weathering for $\mathrm{CO}_{2}$ consumption of a particular lithology, which for all practical purposes is for an epimafic rock. For example, the Siberian Trap and the Deccan Trap basalts may have essentially the same weatherability but because the Siberian Trap basalts are in cold high latitudes, their area-weighted $\mathrm{CO}_{2}$ consumption rate today is more than an order of magnitude less than that of the Deccan Trap basalts (Dessert et al., 2003). The Cenozoic drift into the equatorial humid belt of the highly weatherable Deccan Trap continental basalts followed by obducted ophiolites in arc-continent collision zones like the Indonesian archipelago (Dessert et al., 2001, 2003; Kent and Muttoni, 2008, 2013; Macdonald et al., 2019) provide plausible scenarios for enhanced weathering drawdown of $p \mathrm{CO}_{2}$ to initiate and sustain the Late Cenozoic Ice Age.

The decrease in $p \mathrm{CO}_{2}$ in the Late Paleozoic is commonly attributed to the expansion of land plants and concomitant increase in silicate rock weatherability (Algeo et al., 1995; Berner, 2004; Bergman et al., 2004). Although the colonization of continents by vascular plants occurred much earlier than the onset of the LPIA, as did the emergence of lignin decomposers (Montañez, 2016; Nelsen et al., 2016), the profound increase in biomass with the spread of seed plants in the Late Devonian could have set the stage for the LPIA in the Carboniferous and Permian (Algeo and Scheckler, 1998). In seeking a more proximal cause for a $\mathrm{CO}_{2}$ drawdown, Goddéris et al. (2017) used comprehensive climate and landscape models to argue for enhanced silicate weathering $\mathrm{CO}_{2}$ consumption associated with the mid-Carboniferous rise of a $5000 \mathrm{~m}$ high Variscan (= Hercynian) mountain plateau in the tropics of Pangea; subsequent erosive leveling of the mountain chain culminating with the development of a saprolith shield was supposed to have reduced $\mathrm{CO}_{2}$ weathering drawdown sufficiently to allow atmospheric $\mathrm{CO}_{2}$ concentration to build up and eventually lead to the meltdown of the LPIA in the Early Permian. The mountain uplift and erosion hypothesis of Goddéris et al. (2017) used paleogeographic reconstructions from Golonka (2002) that had an essentially static Pangea configuration from the Late Carboniferous (308 Ma) to the end of the Early Permian $(272 \mathrm{Ma})$, which isolated topography as the main driver of $\mathrm{CO}_{2}$ drawdown in their scenario. Fluteau et al. (2001) had previously focused attention on topographic relief in carbon cycle modeling of Permian climate, and indeed, the LPIA was regarded as the notable exception for paleogeographic setting as the main driver of climate over the entire Paleozoic and well into the Mesozoic (Goddéris and Donnadieu, 2019).

Given the importance of tectonics in modulating $p \mathrm{CO}_{2}$, we note that a generally overlooked context for understanding the LPIA is the supercontinent configuration known as Pangea B in the Carboniferous and Early Permian, its latitudinal drift history and its transformation to the more familiar Pangea A by the Late Permian (e.g., Muttoni et al., 2009a; Gallo et al., 2017). Below we show that Pangea B is well-supported by the most consistent and least biased paleomagnetic data available for the Late Carboniferous and Early Permian and that this configuration essentially coincided with the LPIA. Moreover, the presence of extensive coal basins and extensional volcanism across the equatorial region of Euramerica in the Late Carboniferous-Early Permian is inconsistent with a Variscan mountain plateau reaching up to $5000 \mathrm{~m}$, suggesting that high topographic relief may not be the main driver controlling $\mathrm{CO}_{2}$ drawdown. Instead, we point to evidence that the exhumation of $\mathrm{CaO}$ and $\mathrm{MgO}$-rich Variscan crystalline rocks as well as organic carbon burial occurred in a complex geological and topographic landscape and played reinforcing roles in $\mathrm{CO}_{2}$ consumption as central Pangea drifted northward through the equatorial humid belt. The subsequent tectonic transformation from Pangea B to Pangea A in the mid-Permian coupled with steady northward drift of Pangea into the arid belt of the northern hemisphere reduced the land-to-sea areal distribution in the critical equatorial belt and thus the areal extent of prime venues for continental silicate weathering and equatorial coal forests for the culminating phase of warming and demise of the LPIA by the Late Permian (but not without a hiccup).

\section{Late Paleozoic Ice Age and coal}

The LPIA is characterized by glacial deposits of Carboniferous and Permian age on virtually all Gondwana continents (high to mid-paleolatitude regions of South America, southern Africa, India, Antarctica, and Australia) including extensive glaciomarine deposits, which indicate that the ice sheets reached sea level and thus imply global cooling (Montañez and Poulsen, 2013). The LPIA extended from $\sim 320 \mathrm{Ma}$ in the Early Pennsylvanian ( $\sim$ Bashkirian) of the Carboniferous to $\sim 260 \mathrm{Ma}$ in the Middle Permian (Guadalupian), and perhaps to $\sim 255 \mathrm{Ma}$ in the Late Permian (Lopidigian) (Fig. 1A; geologic time scale (GTS2012) of Gradstein et al. (2012) used throughout). The LPIA is basically contemporaneous with the Kiaman Reverse Polarity Superchron, which extends from the Wanganui Reversal at $\sim 316 \mathrm{Ma}$ in the early part of the Late Carboniferous (Pennsylvanian) (Opdyke et al., 2000 ) to the Illawara mixed polarity zone at $\sim 265 \mathrm{Ma}$ in the Middle Permian (Lanci et al., 2013). Magnetostratigraphy is thus of limited use for global correlation of glacial and associated deposits of the LPIA. Fortunately, wider applications of U-Pb zircon geochronology are providing valuable means of correlations and age constraints in the PermoCarboniferous (Griffis et al., 2019; Machlus et al., 2020; Metcalfe et al., 2015).

Ice centers or glacial pulses developed to their maximum extents in two main phases, one centered at $\sim 315$ Ma (Moscovian of the 


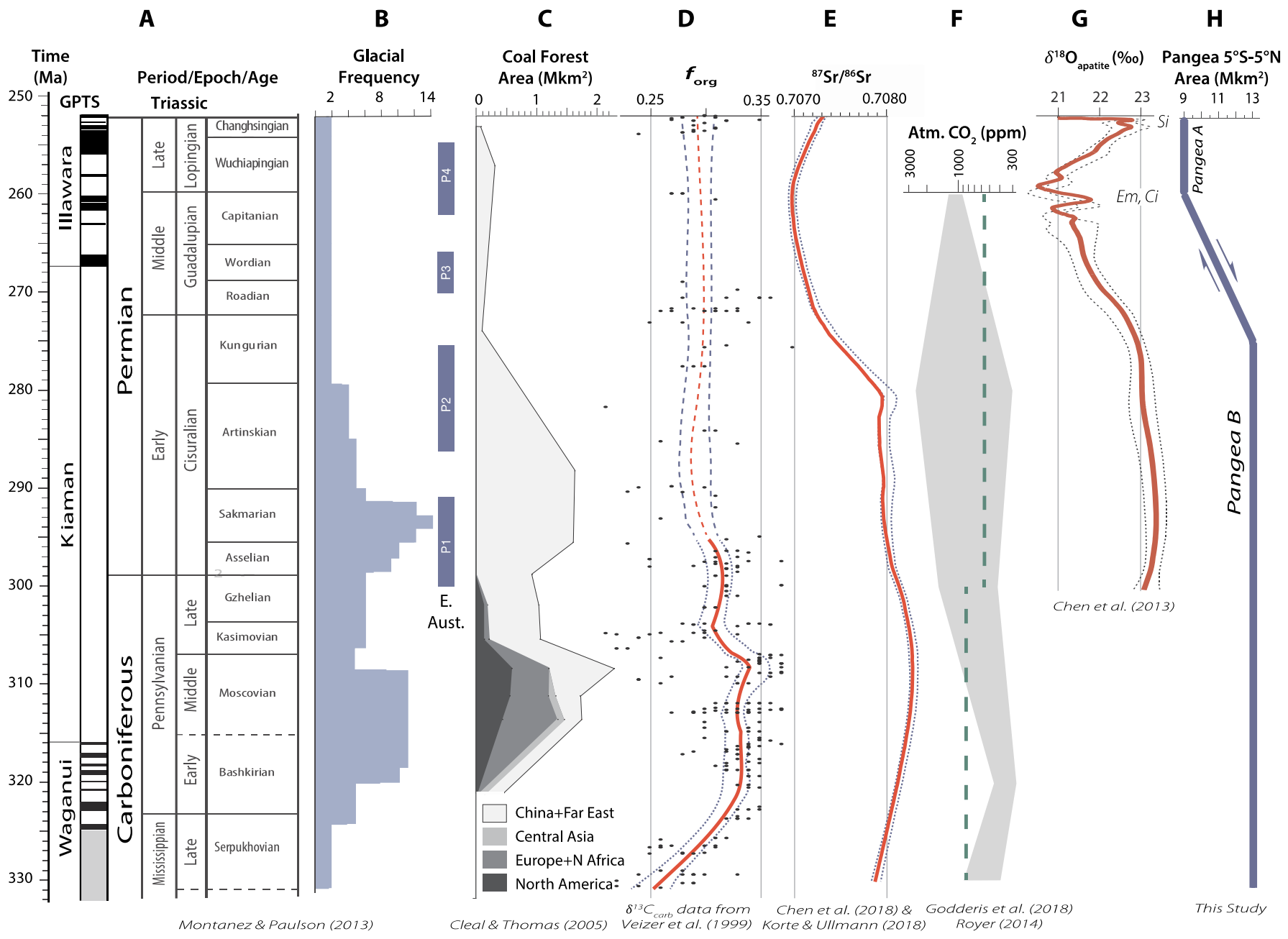

Fig. 1. Chronostratigraphic context for the Late Paleozoic Ice Age and related phenomena in the Carboniferous and Permian. Conditions reflecting or more conducive

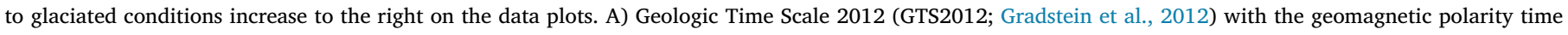

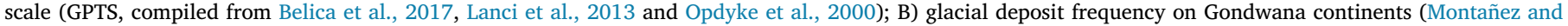

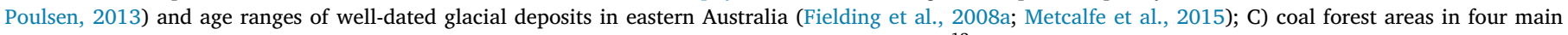

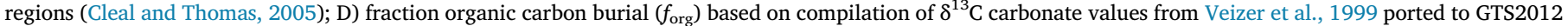

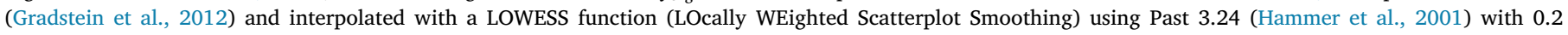

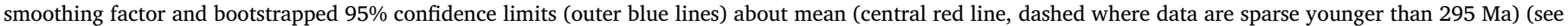

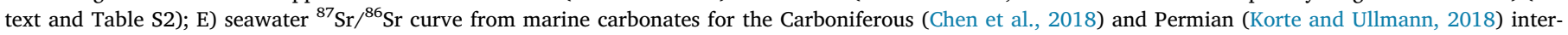

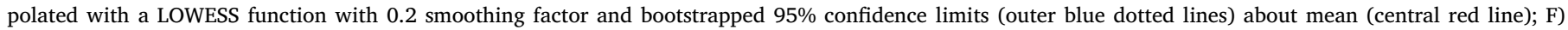

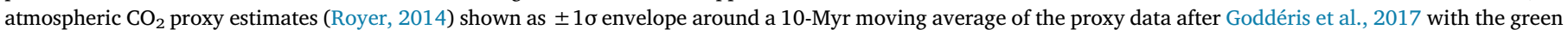

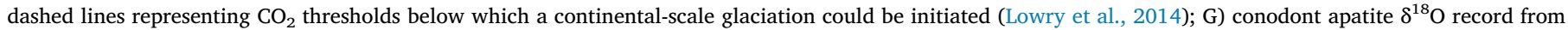

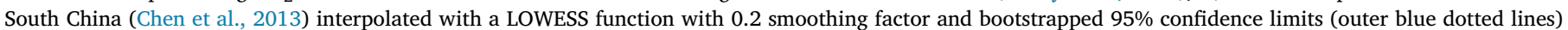

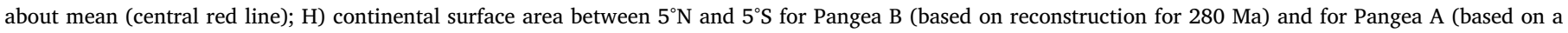

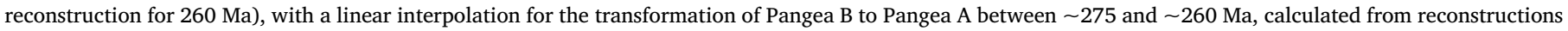

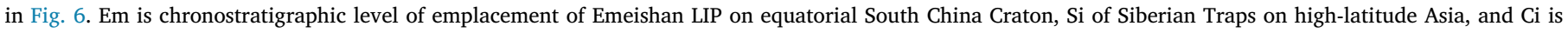

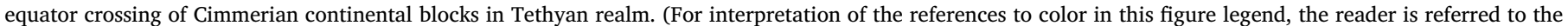
web version of this article.)

Pennsylvanian or Late Carboniferous) and the other at $\sim 295 \mathrm{Ma}$ (Sakmarian in the Cisuralian or Early Permian), after which glacial frequency tailed off by $\sim 280$ Ma (through the Artinksian in the Cisuralian or Early Permian) as continental ice sheets were replaced by alpine glaciers with the remaining ones (in northeastern Australia) mostly gone by $\sim 260 \mathrm{Ma}$, the beginning of the Late Permian (Crowell, 1999; Fielding et al., 2008b; Metcalfe et al., 2015; Montañez and Poulsen, 2013) (Fig. 1B). The classic chronology of the P1-P4 glaciations in Australia (Fielding et al., 2008a; Fielding et al., 2008b) was updated by Metcalfe et al. (2015) using high precision U-Pb zircon geochronology, which indicated younger ages for the P3 and P4 glacial episodes, the latter episode now essentially confined to the Late
Permian and quite possibly representing the youngest glaciation of the LPIA.

Broadly coincident in time with the two main glacial episodes of the LPIA are vast areal extents of coal forests that led to the greatest accumulation of coal in Earth history (Cleal and Thomas, 2005; Feulner, 2017). Peak areal distributions of coal forests occurred in the Pennsylvanian (Late Carboniferous) across regions stretching from eastern North America, Europe, North Africa and Central Asia, with a second coal forest peak in the Cisuralian (Early Permian) mainly in China and the Far East (Ziegler et al., 2003) (Fig. 1C). There seems to be a strong associated signal for organic carbon burial calculated from $\delta^{13} \mathrm{C}$ data on marine carbonates (Veizer et al., 1999) (see below), which shows an 
increase in $f_{\text {org }}$ from around 0.25 at $\sim 330$ Ma to a peak of around 0.35 by 310 Ma that coincides with the Late Carboniferous maximum in coal forest area (Fig. 1D). Significant organic carbon burial in the Late Carboniferous is supported by atmospheric $\mathrm{pO}_{2}$ concentrations, inferred from inertinite percentages in coals, that are higher than in today's atmosphere (Glasspool et al., 2015), suggesting that terrestrial vegetation- $\mathrm{CO}_{2}$ entanglements were also capable of playing a key role in driving orbitally-paced expansions and contractions of continental ice sheets (Horton et al., 2010; Montañez et al., 2016).

The seawater carbonate ${ }^{87} \mathrm{Sr} /{ }^{86} \mathrm{Sr}$ curve (Chen et al., 2018; Korte and Ullmann, 2018) is consistent with continental silicate weathering that was enhanced (although not necessarily globally; Edmond, 1992; Kump and Arthur, 1997) in the Late Carboniferous and Early Permian, decreasing in the late Early and Middle Permian, but then increasing in the Late Permian (Fig. 1E). The low $p \mathrm{CO}_{2}$ concentrations that are generally associated with at least the initial part of the LPIA (Royer, 2014) (Fig. 1F) can be attributed to increased silicate weathering $\mathrm{CO}_{2}$ consumption as suggested by the ${ }^{87} \mathrm{Sr} /{ }^{86} \mathrm{Sr}$ curve, and/or increased organic carbon burial, as suggested by the $f_{\text {org }}$ curve. Seawater temperatures inferred from $\delta^{18} \mathrm{O}$ measurements on conodonts (Chen et al., 2013) (Fig. 1G) show that the ultimate waning phase of the LPIA occurred at $\sim 275 \mathrm{Ma}$ in the latest Early Permian with a steep increase in temperatures to about $260 \mathrm{Ma}$. However, temperatures then sharply decrease starting about $260 \mathrm{Ma}$ coinciding with the emplacement of the Emeishan large igneous province (Chen et al., 2013) and at about the same time as the Late Permian increase in ${ }^{87} \mathrm{Sr} /{ }^{86} \mathrm{Sr}$ values (Fig. 1E), which may mark the passage of the Cimmerian continental blocks through the equatorial humid belt (see below).

In the widely used GEOCARB-style models, the fuzzy increase in atmospheric $p \mathrm{CO}_{2}$ concentrations toward the end of the LPIA (Montañez et al., 2007) has traditionally been attributed to an increase in $\mathrm{CO}_{2}$ outgassing (Berner, 1991, 1994, 2006; Berner and Kothalava, 2001), an assertion that is difficult to verify or refute. More tractable to evaluate is an increasing $p \mathrm{CO}_{2}$ content resulting from decreasing silicate weatherability across an eroded landscape (Goddéris et al., 2017) with possibly decreasing organic matter burial (Birgenheier et al., 2010). Here we estimate the timing and magnitude of changes in landsea distribution in the equatorial humid belt and resultant changes in silicate weatherability and terrestrial vegetation habitat from the collision of Gondwana and Laurasia that resulted in the Greater Variscan (Alleghenian-Mauritanide-Hercynian) orogeny at the core of a Pangea B (rather than Pangea A) configuration, its continued northward drift across climate belts, and its transformation to Pangea A in the midPermian (Fig. 1H) as the tectonic framework for the LPIA.

\section{Pangea $B$ and transformation to Pangea A}

The familiar Wegenerian model of Pangea, similar to what has become the classic Bullard computer fit of the Atlantic-bordering continents (Bullard et al., 1965), is widely assumed to have persisted in basically the same configuration for practically the entire $150 \mathrm{Myr}$ nominal lifespan of the supercontinent. In this popular view (e.g., Scotese and Langford, 1995; Veevers and Tweari, 1995; Torsvik et al., 2012), a Pangea A-type configuration started with the collision that produced the Greater Variscan Orogen between the northern (Laurasia) and southern (Gondwana) supercontinental assemblies at $\sim 330 \mathrm{Ma}$ until breakup and dispersal starting in the Jurassic at 180 Ma. Pangea A of Golonka (2002) is the paleogeographic framework used by Goddéris et al. (2017) for modeling Late Paleozoic climate from 323 Ma to $272 \mathrm{Ma}$; a reconstruction used in their climate model for the Moscovian ( $\sim 308 \mathrm{Ma})$, when the Greater Variscan Orogen was presumed to have had its greatest relief, is shown in Fig. 2 (top).

There has nonetheless been a longstanding empirical discrepancy with the classic Wegenerian model of Pangea in the Carboniferous-Early Permian that developed in close relationship with the concept of Adria as a promontory of Africa (Argand, 1924; Channell and Horvath, 1976). The historical development of these ideas is described elsewhere (Muttoni and Kent, 2019a). In brief, Van Hilten (1964) showed that paleomagnetic data from Early Permian volcanics from the Southern Alps of northern Italy, part of Adria, implied paleolatitudes too northerly relative to those documented from now-adjacent parts of Europe but which were curiously compatible with the available paleomagnetic record from contemporaneous rock units in Africa. This creates a geometrical problem because Adria with Africa could not be reconstructed with Europe in a Pangea A-type configuration without untenable crustal overlap between the southern margin of Laurasia and the northern margin of Gondwana. Attempts to reconcile this discrepancy initially led to the concept of the 'Tethys Twist' (Van Hilten, 1964; de Boer, 1965), a tectonic dance of Laurasia and Gondwana that was soon disavowed because of its improbably long postulated duration and incompatibility with other evidence from the emerging strictures of plate tectonics (Zijderveld et al., 1970).

Despite serial attempts at alternative explanations for the misfit in the paleomagnetic data, such as standing non-dipole fields and data selection artifacts (see discussion and references in Domeier et al. (2012)), straightforward analyses of reliable modern data continued to require a different configuration of Pangea in its earlier stage (Muttoni et al., 1996, 2003, 2009a, 2009b; Rakotosolofo et al., 2006; Angiolini et al., 2007; Gallo et al., 2017). Based on these previous studies and the updated analyses presented below, we maintain that the most parsimonious paleocontinental model is Pangea B (Irving, 1977, 2004; Morel and Irving, 1981), a configuration with the northwestern margin of South America adjacent to eastern North America that lasted from the Early Carboniferous to the Early Permian, and which according to our interpretation of current paleomagnetic data, transformed by the Late Permian to a Pangea A-type configuration (Bullard et al., 1965; Van der Voo and French, 1974), with the northwestern margin of Africa now against eastern North America. Our model of Pangea B for the Late Carboniferous, based on the best available paleomagnetic data averaged in a $20 \mathrm{Myr}$ time window centered on $310 \mathrm{Ma}$ as described below, is illustrated in Fig. 2 (bottom).

Some of the main differences apparent in the reconstructions shown in Fig. 2 that are likely to have consequences in attempts to explain the LPIA according to the $\mathrm{CO}_{2}$ paradigm and motivate closer scrutiny of the paleogeographic context are: 1) the larger land area within the equatorial humid belt for Pangea B (Fig. 2 bottom) compared to Pangea A (Fig. 2 top); 2) the position of the Greater Variscan orogen, that was steadily eroded and the key $p \mathrm{CO}_{2}$ sink for the LPIA in the modeling of Goddéris et al. (2017), is closer to the equator in Pangea B than in this model of Pangea A; 3) the unexplained geographic juxtaposition of the supposed high Greater Variscan plateau with major coal basins in Europe, which may be significant sinks of organic carbon.

\subsection{Updated test for Pangea $B$}

The Pangea B configuration for the Early Permian proposed by Muttoni et al. (2009b) used paleomagnetic poles from igneous units from Europe to position Laurasia and from Africa (plus parautochthonous Adria) to position Gondwana in a common latitudinal framework. A subsequent critical analysis (Domeier et al., 2012) questioned the use of paleopoles from parautochthonous Adria as potentially rotated relative to stable Africa; indeed, Adria data have been excluded from most inventories of global reference poles because of this uncertain tectonic affiliation (e.g., Kent and Irving, 2010; Torsvik et al., 2012). On the other hand, pole listings like those of Torsvik et al. (2012) and Domeier et al. (2012) tend to be dominated by sedimentary poles that are likely to be biased by inclination error. We make a critical reappraisal of the global database listed in Torsvik et al. (2012) in an attempt to identify what might be the cause(s) of the deep disparity in interpretations of Pangea paleogeography in the Permian. The testable null hypothesis is Pangea A existed over the entire Permian, as advocated, for example, by Torsvik et al. (2012), Domeier et al. (2012) 


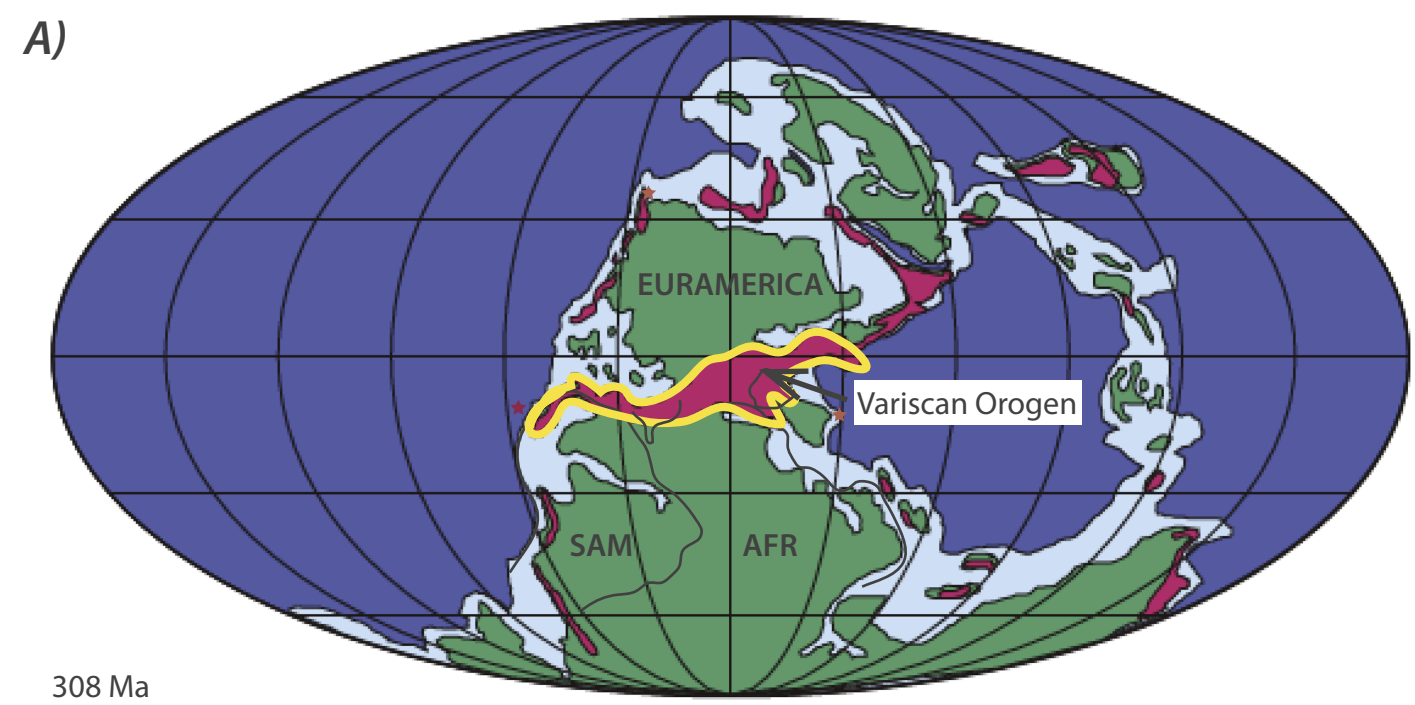

Late Carboniferous (Golonka, 2002; Godderis et al., 2017)

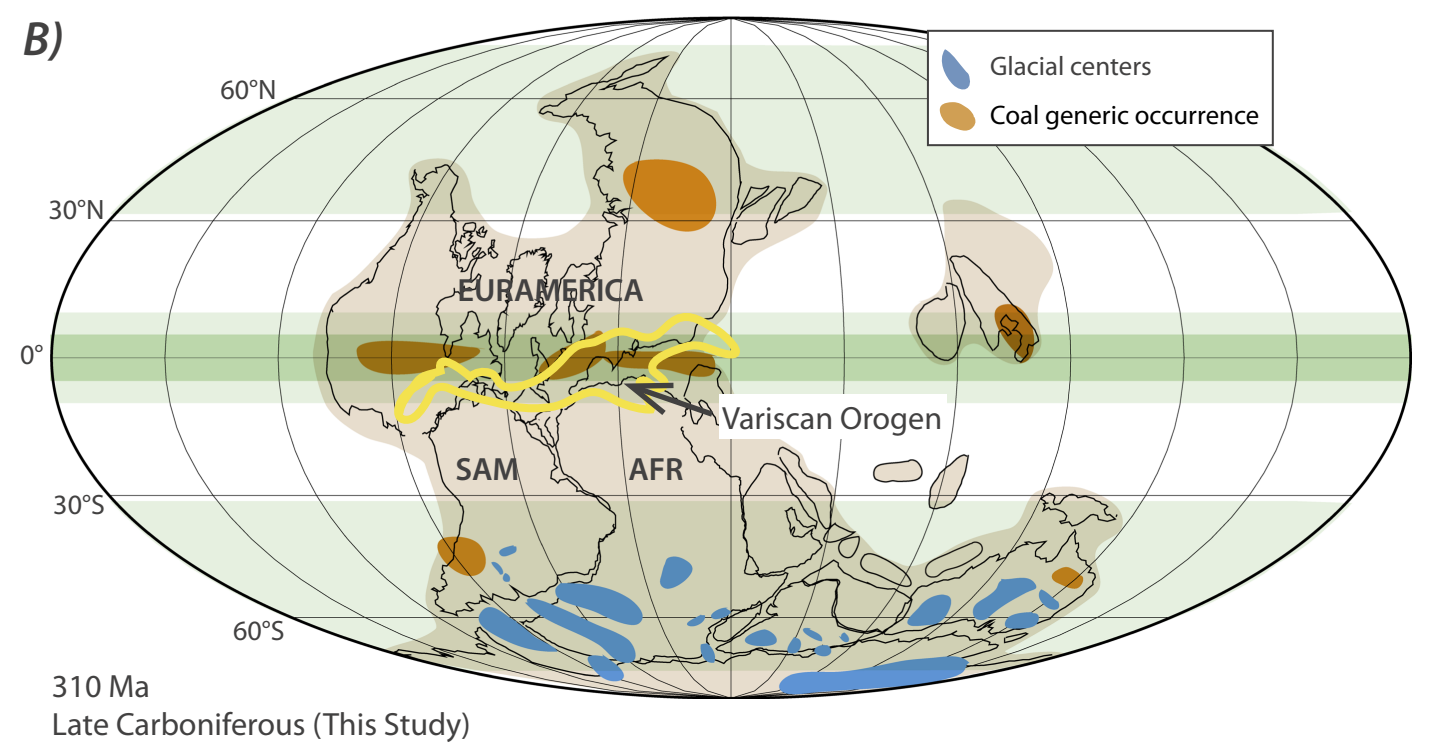

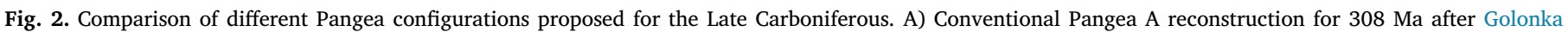

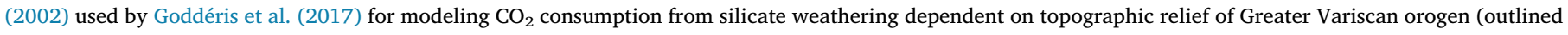

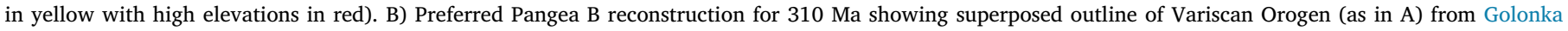

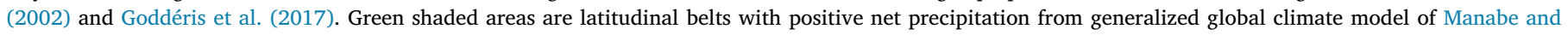
Bryan (1985) (see also Fig. 7). (For interpretation of the references to color in this figure legend, the reader is referred to the web version of this article.)

and Golonka (2002), and used for climate modeling of the LPIA by Goddéris et al. (2017).

We extracted from the listing of paleomagnetic reference poles in Torsvik et al. (2012) those entries with assigned ages in the approximately 100 Myr interval (350-250 Ma) encompassing the Carboniferous and Permian Periods that are based on igneous units and sedimentary units explicitly corrected for inclination error using E/I or Imethods (Tauxe and Kent, 2004; Bilardello and Kodama, 2010a) from Europe, Siberia and North America (representing Laurasia) and from South America, Africa (including Adria) and Australia (representing Gondwana). We chose data (Table S1) from intrusive and extrusive igneous rocks because these would not be affected by sedimentary inclination error; exceptions are entry \#6 with interbedded sediments, $\# 14$ an igneous breccia, and entries \#56, \#58, \#61, \#63, \#66, \#67, and \#71, which comprise sedimentary data that were E/I or I-corrected for inclination shallowing. For Gondwana, we also included data as indicated below from Africa, Australia, and parautochthonous Adria from igneous and E/I or I-corrected sedimentary units that were not used in Torsvik et al. (2012). The only igneous result excluded in this broad time window was the Punta del Agua pole from Argentina, which according to the original authors (Geuna and Escosteguy, 2004) could be affected by grossly incorrect age assignment and/or remagnetization and/or tectonic rotations.

For Laurasia, these criteria yielded 66 poles ranging in age from 250 Ma to 335 Ma mainly from Europe (48 poles) plus the Siberian Traps (10 poles), and from North America ( 8 poles), or $58 \%$ of the 113 reference poles listed by Torsvik et al. (2012) (Fig. 3A; Table S1). Paleomagnetic poles for Gondwana are much sparser; these criteria yielded only 12 poles ranging in age from 263 Ma to 348 Ma (6 from South America, 5 from Africa, and 1 from Australia), or only $29 \%$ of the 42 reference poles listed by Torsvik et al. (2012). To these we add 3 igneous poles from Australia (Mt. Leyshon Intrusives and Tuckers 
Igneous Complex, dated at $286 \pm 6$ Ma (Clark and Lackie, 2003), and the Rocky Hills Syncline section, dated at $\sim 313$ Ma (Opdyke et al., 2000)), a recently published E/I corrected sedimentary pole from Late Permian ( $\sim 266.5 \mathrm{Ma})$ Karoo redbeds in South Africa (Lanci et al., 2013), as well as seven entries from igneous units and an E/I corrected sedimentary unit from parautochthonous Adria (Muttoni et al., 2003, 2009a) also not listed in Torsvik et al. (2012), which provide a total of 24 poles for the Carboniferous and Permian of Gondwana (Fig. 3B, Table S1).

As described, one-third (8) of the 24 accepted poles for the Carboniferous and Permian for Gondwana come from Adria (Table S1). Given the numerical weight of the Adria dataset and its neglect in most analyses of reference poles and Pangea paleogeography, we compare the mean of the Adria poles for the Early Permian $(N=7$, mean age $280 \mathrm{Ma}$; ID20 in Table 1) with the mean of the other Early Permian poles for Gondwana from NW Africa, NE Africa, Australia and South America in NW African coordinates according to the preferred reconstruction parameters of Lottes and Rowley (1990) $(N=5$, age range 273-286 Ma, mean age $281 \mathrm{Ma}$; ID21). The mean poles are not significantly different, separated by only $3.6^{\circ}$ arc distance and well within their respective circles of $95 \%$ confidence (Fig. 4). This supports the tectonic coherence of parautochthonous Adria with NW Africa observed in paleomagnetic data of Permian as well as Triassic, Jurassic, Cretaceous, and Cenozoic age (e.g., Channell and Horvath, 1976; Channell et al., 1979; Muttoni et al., 2003; Muttoni and Kent, 2019b), which is the conceptual foundation of Pangea B in the Early Permian (Muttoni and Kent, 2019a). We are thus justified in freely incorporating Adria poles with those from NW Africa in calculating mean poles for Gondwana. We also note that a recent kinematic synthesis of the Mediterranean region by van Hinsbergen et al. (2020) implied a net rotation of nearly $18^{\circ}$ of Adria with respect to NW Africa from $220 \mathrm{Ma}$ and before (Euler pole: $49.5^{\circ} \mathrm{N}-10.16^{\circ} \mathrm{E}-17.99^{\circ}$ delta; D. van Hinsbergen, 2020, pers. comm.); however, the corresponding correction would significantly separate the Adria and Gondwana mean 280 Ma poles (Fig. 4), in strong disagreement with their kinematic reconstruction of Adria.

To facilitate comparisons with the inventory of Carboniferous and Permian poles compiled for Laurasia and Gondwana by Torsvik et al. (2012) we largely drew from, we calculated mean poles in $20 \mathrm{Myr}$ sliding windows and focus on the independent mean poles centered on 260 Ma for the Late Permian, 280 Ma for the Early Permian, and 310 Ma for the Late Carboniferous (Table 1). The Late Carboniferous and Permian poles for Laurasia and Gondwana make northerly-trending swaths with respect to each supercontinent (Fig. 4). For Laurasia, the 260, 280 and 310 Ma means reported by Torsvik et al. (2012, their Table 5) and those we estimated here are generally within their respective circles of confidence, whether or not the sedimentary results had been corrected with the blanket flattening factor of 0.6 applied by Torsvik et al. (2012) (Fig. 4). This mutual agreement is most likely because more than half (66 of 113) of the Carboniferous and Permian reference poles listed by Torsvik et al. (2012) for Laurasia are igneous.

The tally is about the opposite for Gondwana: $>2 / 3(71 \%, 30$ of 42$)$ of the Carboniferous and Permian poles listed in Torsvik et al. (2012) are from sedimentary units so that any application of an expedient blanket correction for inclination error to the predominant population of sedimentary unit results can be expected to have larger effects on the mean poles. And indeed, the $260 \mathrm{Ma}$ and $280 \mathrm{Ma}$ mean poles shift by $7.4^{\circ}$ and $5.7^{\circ}$, respectively, with correction by a blind flattening factor of 0.6 , and away from the appreciably more precise (up to five times higher precision parameter $\mathrm{K}$ ) igneous and $\mathrm{E} / \mathrm{I}$ or I-corrected mean poles of corresponding window age deduced from our analysis (Table 1; Fig. 4). This behavior can be understood as due to overcorrection for inclination error, as might happen for heavily overprinted magnetizations, and strongly suggests that the appropriate flattening factor correction must be determined directly rather than assumed for each sedimentary result.

\section{Permo-Carboniferous poles (250 - $350 \mathrm{Ma})$}

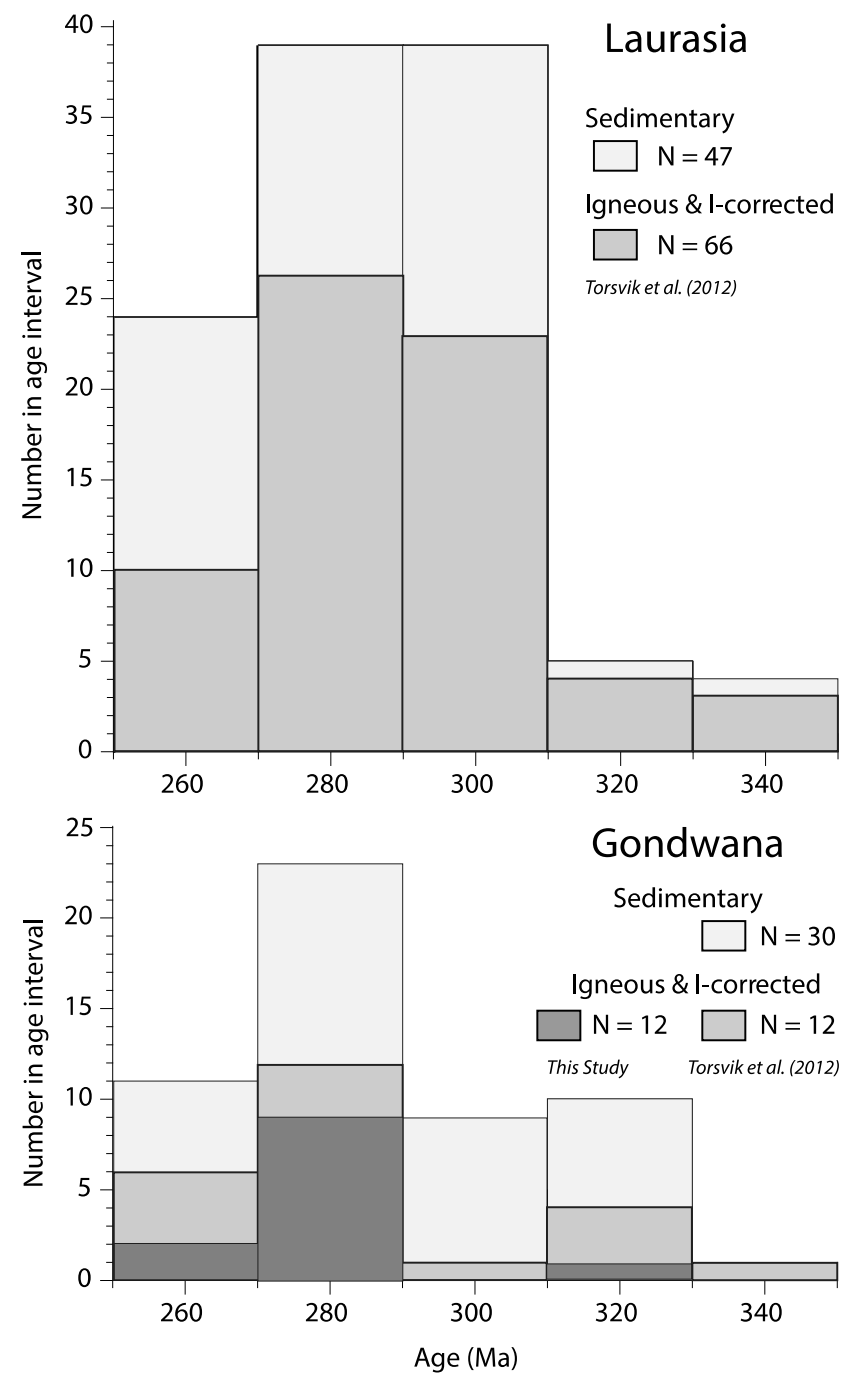

Fig. 3. Histogram of Carboniferous and Permian reference poles in $20 \mathrm{Myr}$ age bins for Laurasia (top) and Gondwana (bottom) from compilation in Torsvik et al., 2012 plus additional igneous and E/I or I-corrected results from Gondwana (see text and Table S1).

The arc-distance between our $310 \mathrm{Ma}$ and 260 Ma mean poles for Gondwana reflects $20.2 \pm 8.9^{\circ}$ of apparent polar motion, almost the same as that of Laurasia $\left(21.4 \pm 8.6^{\circ}\right)$ over a similar 310 to $260 \mathrm{Ma}$ (Late Carboniferous to Late Permian) time interval. We speculate that this congruence of apparent motion of virtually all the world's landmass could represent a candidate for true polar wander, a rotation about an equatorial Euler pivot of the solid body of Earth with respect to its spin axis (approximated by the time-averaged geomagnetic field according to the geocentric axial dipole hypothesis) that can arise from uncompensated redistributions of mass affecting the planet's moment of inertia (Gold, 1955; Goldreich and Toomre, 1969; Tsai and Stevenson, 2007). Ice sheets, such as the Gondwana glaciations, may provide suitable load-induced perturbations to the inertia tensor to drive true polar wander (Mitrovica and Wahr, 2011).

Proceeding to evaluate the paleogeographic consequences of Laurasia and Gondwana mean poles for the Carboniferous and Permian, we first test the null hypothesis of a Pangea A configuration in the Early Permian. For Laurasia, we use the well-populated $280 \mathrm{Ma}$ window mean with igneous and $\mathrm{E} / \mathrm{I}$ or I-corrected poles (ID4, $N=26$, average age $281 \mathrm{Ma}$ ) and compare it to the $280 \mathrm{Ma}$ igneous and E/I or I- 


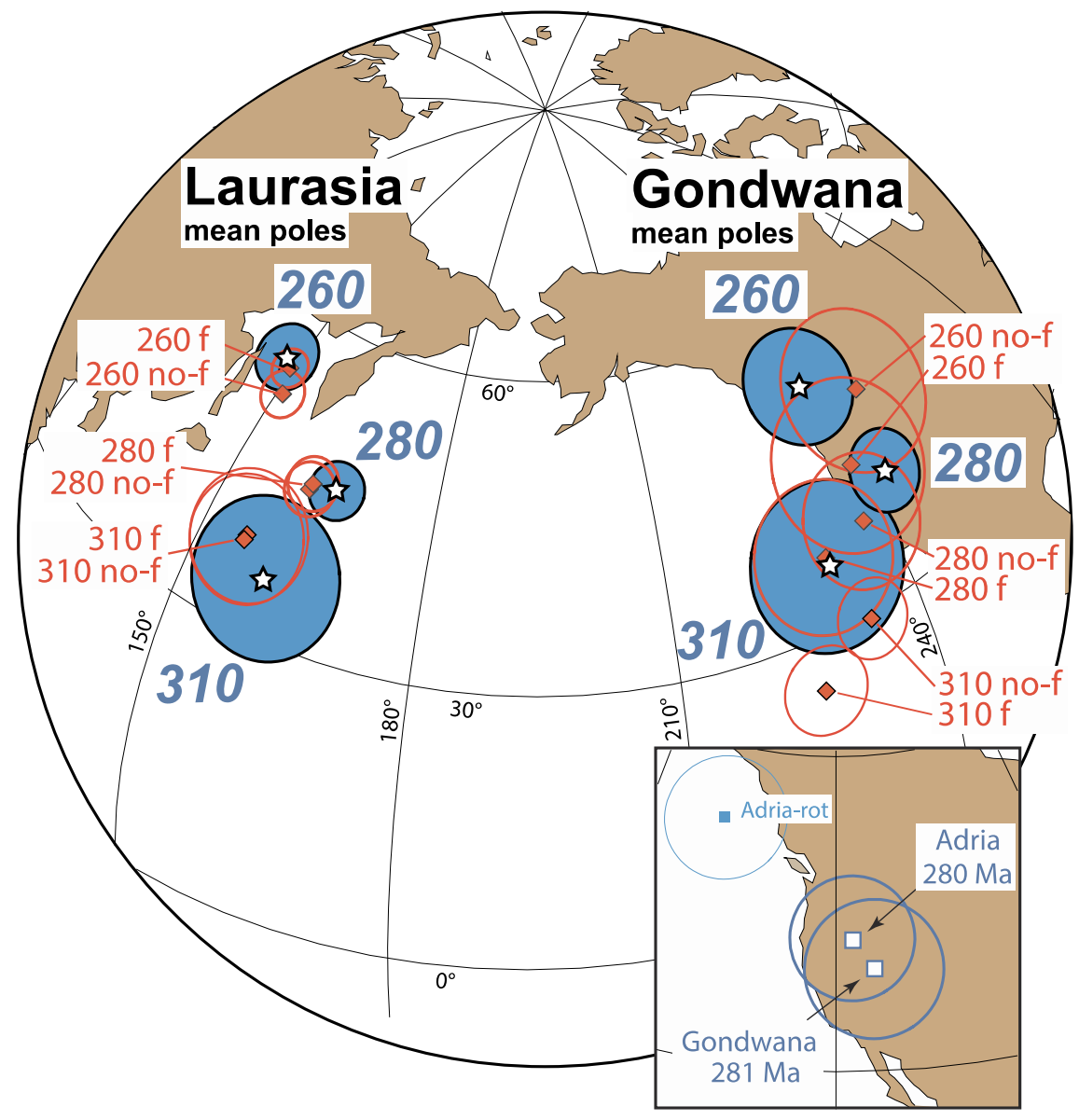

Fig. 4. Mean poles for independent 20 Myr age bins centered at $260 \mathrm{Ma}, 280 \mathrm{Ma}$ and $310 \mathrm{Ma}$ for Laurasia (European coordinates) and Gondwana (NW Africa coordinates) for igneous and E/I or I-corrected results only compiled here (stars with A95s in filled blue) compared to those that include results from sedimentary units before (no-f) and after (f) blanket correction factor of $\mathrm{f}=0.6$ from Torsvik et al. (2012) (diamonds with open A95s as labeled). See Table 1 for listings. Inset shows comparison of Adria mean pole for $280 \mathrm{Ma}$ and for rest of Gondwana for $281 \mathrm{Ma}$; also shown (Adria-rot) is the Adria mean pole rotated with respect to NW Africa (Euler pole at $49.5^{\circ} \mathrm{N}-10.16^{\circ} \mathrm{E}-17.99^{\circ}$ delta) according to tectonic kinematic model for Mediterranean region of van Hinsbergen et al. (2020). (For interpretation of the references to color in this figure legend, the reader is referred to the web version of this article.) corrected mean pole for Gondwana (ID22, $N=12$, average age $280 \mathrm{Ma}$ ) (Table 1). Although it may not be a decisive factor, we note that 'Bullard fit' Laurasia mean poles and 'Lottes\&Rowley fit' Gondwana mean poles tend to be better grouped than mean poles obtained using the rotation parameters of Torsvik et al. (2012) and are thus preferred here. In any case, the test of Pangea A in the Early Permian fails (Fig. 5A). To avoid an untenable continental overlap between the facing margins of Laurasia and Gondwana, the most economical reconciliation is shifting Gondwana eastward relative to Laurasia (Fig. 5B); this is the operational basis of the Pangea B model (Irving, 1977; Morel and Irving, 1981) and the rationale for more recent models like Muttoni et al. (2009a). We stress that the Pangea A test fails with or without data from parautochthonous Adria. The somewhat younger $260 \mathrm{Ma}$ Laurasia and Gondwana igneous and E/I or I-corrected mean poles (ID1 and ID16, Table 1) do, however, allow a Pangea A-type configuration by the Late Permian (Fig. 5C).

Pangea A-type configurations are nevertheless typically used for the Early Permian (e.g., Fig. 19 in Golonka (2002), Fig. 22 in Domeier et al. (2012)), or the 'Permo-Carboniferous' (Fig. 19 in Torsvik et al. (2012)). We diagnose the discrepancy as largely due to deficiencies of the Gondwana pole dataset and draw attention to the $20 \mathrm{Myr}$ window mean poles of Torsvik et al. (2012) with sedimentary results uniformly deflattened with $\mathrm{f}=0.6$ (their Table 7 , all rotated to NW African coordinates in Table 1 ) that are shifted $>10^{\circ}$ compared to our Gondwana igneous and E/I or I-corrected mean poles (Fig. 4). For example, their mean 280 Ma pole with no flattening correction (ID24 in Table 1) falls $5.5^{\circ}$ from our $280 \mathrm{Ma}$ igneous and E/I or I-corrected mean pole (ID22) but their 280 Ma mean pole with blanket flattening correction with $\mathrm{f}=0.6$ (ID25) falls $10.7^{\circ}$ from our mean 280 Ma pole. This suggests that blind application of a deflattening factor is overcorrecting inclinations for at least some of the sedimentary results, as evidenced also by the general decrease in precision with blanket corrections (Table 1).

Despite mounting evidence for the prevalence of inclination error in sedimentary units (e.g., Tauxe and Kent, 2004; Bilardello and Kodama, 2010b; Kent and Irving, 2010), the lower precision with blanket application of a sedimentary deflattening factor points to exacerbating problems with the predominantly sedimentary poles for Gondwana (and probably Laurasia) in the listings of Torsvik et al. (2012). A blanket deflattening adjustment to sedimentary results contaminated by post-compaction chemical remagnetizations (e.g., see papers in Elmore et al., 2012) would introduce deviations by overcorrection while amplifying already large age uncertainties often associated with studied continental sediments. For example, sample demagnetization trajectories moving on great circle paths without reaching stable end-points and indicative of remagnetizations are frequently observed in various Carboniferous-Permian sedimentary units from north Africa (e.g., Derder et al., 1994, 2019) and South America (e.g., Font et al., 2012; Bilardello et al., 2018), whereas even those sedimentary units that may have survived remagnetization are frequently affected by poor age control. For example, the Santa Fé Group of Brazil has only a generic Permo-Carboniferous age attribution (Brandt et al., 2009), making it difficult to draw conclusive implications for Pangea geometry (e.g., see Fig. 13 in Brandt et al. (2009)). Radiometric age estimates tend to be more available for the igneous units listed in Torsvik et al. (2012) although problems remain concerning outdated decay constants and/or large experimental errors that affect some of the vintage entries (see also Muttoni et al. (2003) for a critical assessment of ages of Permian paleopoles).

These caveats notwithstanding, the significant $\left(\sim 11^{\circ}\right)$ difference between our $280 \mathrm{Ma}$ Gondwana igneous and E/I or I-corrected mean pole (ID22, Table 1) and the 280 Ma Gondwana pole (ID25) with arbitrarily deflattened sedimentary results (and recommended by Torsvik 
Table 1

Carboniferous and Permian mean paleomagnetic poles for Laurasia and Gondwana.

\begin{tabular}{|c|c|c|c|c|c|c|c|c|c|}
\hline ID & C.Age (Ma) & M.Age (Ma) & Lat $\left({ }^{\circ} \mathrm{N}\right)$ & Lon $\left({ }^{\circ} \mathrm{E}\right)$ & A95 $\left({ }^{\circ}\right)$ & $\mathrm{N}$ & $\mathrm{K}$ & Reference & Notes \\
\hline \multicolumn{10}{|c|}{ Mean paleopoles for Laurasia in European coordinates } \\
\hline 1 & 260 & $254 \pm 7$ & 54.7 & 147.7 & 3.3 & 10 & 210 & \#1-10 (250-269 Ma) & EUR poles only \\
\hline 2 & 260 & & 51.6 & 151.0 & 2.3 & 25 & 148 & Torsvik et al. (2012) & no $f$ \\
\hline 3 & 260 & & 54.0 & 149.5 & 1.9 & 25 & 217 & Torsvik et al. (2012) & f \\
\hline 4 & 280 & $281 \pm 6$ & 45.9 & 165.5 & 2.8 & 26 & 102 & \#11-36 (270-289 Ma) & Bullard fit \\
\hline 5 & 280 & $281 \pm 6$ & 45.6 & 162.7 & 3.3 & 26 & 73 & \#11-36 (270-289 Ma) & Torsvik fit \\
\hline 6 & 280 & & 45.0 & 161.8 & 2.6 & 39 & 74 & Torsvik et al. (2012) & no $f$ \\
\hline 7 & 280 & & 45.6 & 162.0 & 2.6 & 39 & 74 & Torsvik et al. (2012) & f \\
\hline 8 & 310 & $311 \pm 8$ & 35.3 & 160.5 & 7.9 & 8 & 50 & \#56-63 (303-322 Ma) & Bullard fit \\
\hline 9 & 310 & $311 \pm 8$ & 33.9 & 154.6 & 0.5 & 8 & 29 & \#56-63 (303-322 Ma) & Torsvik fit \\
\hline 10 & 310 & & 37.9 & 156.4 & 6.2 & 14 & 36 & Torsvik et al. (2012) & no $f$ \\
\hline 11 & 310 & & 38.3 & 156.5 & 6.4 & 14 & 34 & Torsvik et al. (2012) & $\mathrm{f}$ \\
\hline 12 & 330 & $334 \pm 2$ & 15.7 & 156.8 & 8.9 & 3 & 195 & \#64-66 (332-335 Ma) & Bullard fit \\
\hline 13 & 330 & $334 \pm 2$ & 14.8 & 153.6 & 3.5 & 3 & 1232 & \#64-66 (332-335 Ma) & Torsvik fit \\
\hline 14 & 330 & & 19.0 & 153.1 & 6.3 & 7 & 71 & Torsvik et al. (2012) & no $f$ \\
\hline 15 & 330 & & 17.7 & 153.1 & 6.0 & 7 & 78 & Torsvik et al. (2012) & $\mathrm{f}$ \\
\hline \multicolumn{10}{|c|}{ Mean paleopoles for Gondwana in NW Africa coordinates: } \\
\hline 16 & 260 & $263 \pm 5.5$ & 52.7 & 238.6 & 5.7 & 6 & 138 & \#67-72 (252-267 Ma) & Lottes\&Rowley fit \\
\hline 17 & 260 & $263 \pm 5.5$ & 47.9 & 240.1 & 5.8 & 6 & 133 & \#67-72 (252-267 Ma) & Torsvik fit \\
\hline 18 & 260 & & 49.1 & 246.5 & 8.0 & 10 & 31 & Torsvik et al. (2012) & no $f$ \\
\hline 19 & 260 & & 43.7 & 239.2 & 8.4 & 10 & 28 & Torsvik et al. (2012) & f \\
\hline 20 & 280 & $280 \pm 3$ & 42.7 & 242.1 & 5.9 & 7 & 105 & \#75-81 (ADR only) & \\
\hline 21 & 280 & $281 \pm 5$ & 39.7 & 244.7 & 6.6 & 5 & 134 & $\# 73,74,82-84$ (no ADR) & Lottes\&Rowley fit \\
\hline 22 & 280 & $280 \pm 3$ & 41.4 & 243.2 & 4.0 & 12 & 119 & \#73-84 (273-286 Ma) & Lottes\&Rowley fit \\
\hline 23 & 280 & $280 \pm 3$ & 40.5 & 244.2 & 4.5 & 12 & 93 & \#73-84 (273-286 Ma) & Torsvik fit \\
\hline 24 & 280 & & 38.5 & 237.1 & 6.5 & 17 & 27 & Torsvik et al. (2012) & no $f$ \\
\hline 25 & 280 & & 37.2 & 230.5 & 7.4 & 17 & 21 & Torsvik et al. (2012) & $\mathrm{f}$ \\
\hline 26 & 310 & $311 \pm 8$ & 36.2 & 230.6 & 8.2 & 5 & 87 & \#85-89 (300-321 Ma) & Lottes\&Rowley fit \\
\hline 27 & 310 & $311 \pm 8$ & 30.3 & 232.4 & 8.2 & 5 & 87 & \#85-89 (300-321 Ma) & Torsvik fit \\
\hline 28 & 310 & & 29.6 & 233.5 & 3.9 & 14 & 92 & Torsvik et al. (2012) & no $f$ \\
\hline 29 & 310 & & 25.0 & 225.9 & 4.4 & 14 & 72 & Torsvik et al. (2012) & f \\
\hline 30 & 348 & 348 & 18.8 & 211.2 & 7.5 & 1 & & $\# 90$ & Only one pole \\
\hline 31 & 340 & 348 & 18.8 & 211.2 & 7.5 & 1 & & Torsvik et al. (2012) & Same one pole \\
\hline
\end{tabular}

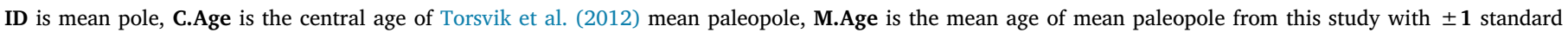

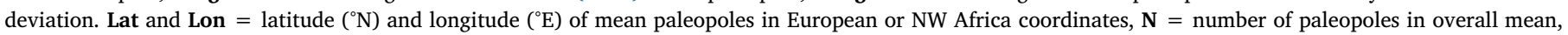

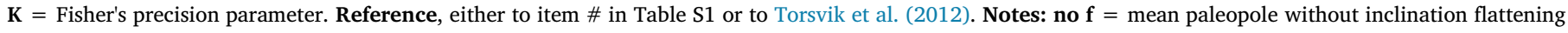

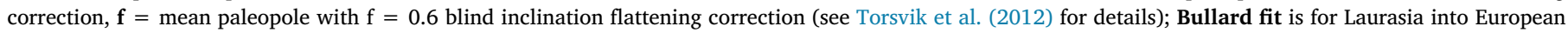

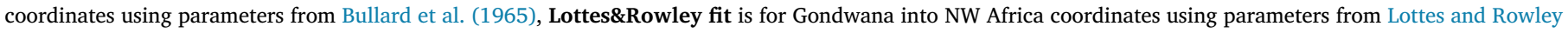

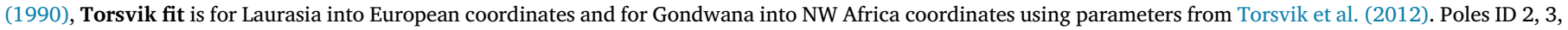

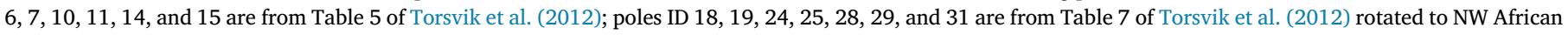
coordinates using rotation parameters of Torsvik et al. (2012).

et al. (2012) as reliable), when each are compared to the 280 Ma mean poles for Laurasia that are dominated by igneous results and thus rather similar in mean direction whether or not the sedimentary results are deflattened (ID6 and ID7, Table 1), largely accounts for why the Pangea A test fails in the Early Permian when our preferred Gondwana mean 280 Ma pole (ID22) is used (Fig. 5A), whereas Pangea A is seemingly not precluded when the mean Gondwana pole with uniformly deflattened sedimentary results recommended by Torsvik et al. (2012) (ID25) is used. We suggest that the best available data provide little empirical evidence to reject Pangea B in the Early Permian (Fig. 5B) or the Carboniferous (see below).

As for timing, specific evidence indicates that the transformation from Pangea B to Pangea A occurred after the Early Permian volcanic pulse that occurred across Europe, as represented for example by the well-dated volcanics of the Dolomites in northern Italy with U-Pb dates of 285-277 Ma (Schaltegger and Brack, 2007; Visonà et al., 2007) and which have paleomagnetic directions supportive of Pangea B (Muttoni et al., 2009a), but before deposition of the overlying sediments of Late Permian age with paleomagnetic directions that support Pangea A (Muttoni et al., 2003) and which also record magnetic polarity reversals of the Illawarra mixed polarity zone, just after the Kiaman reverse polarity superchron presently estimated at $\sim 265$ Ma (Lanci et al., 2013) (Fig. 1). Hence the Pangea B to Pangea A transformation occurred broadly between $\sim 275 \mathrm{Ma}$ and $\sim 260 \mathrm{Ma}$. This event postdated cooling of the Variscan basement and its timing is independently supported by appropriately timed tectonic rotations about local vertical axes along the postulated right-lateral megashear between Laurasia and Gondwana of crustal blocks now preserved in Corsica-Sardinia and southern France (Aubele et al., 2012, 2014; Bachtadse et al., 2018) and possibly elsewhere such as the western Alps (Garde et al., 2015) and the Pyrenees (Şengör et al., 2013), but not to be confused with oroclinal rotations in Iberia, which are older (Carboniferous) and more plausibly linked with Laurasia-Gondwana convergence (Pastor-Galán et al., 2018). The Pangea B configuration places Africa far enough to the east to address the problem of the missing continental plate that collided with the European plate to produce the Variscan orogeny (Arthaud and Matte, 1977) and may also not exclude involvement in the Carboniferous Ouachita-Marathon Orogeny if the Maya-Yucatan and similar blocks were placed way to the west along northwestern South America as revealed by $\mathrm{U} / \mathrm{Pb}$ geochronology and provenance data (Martens et al., 2009). 

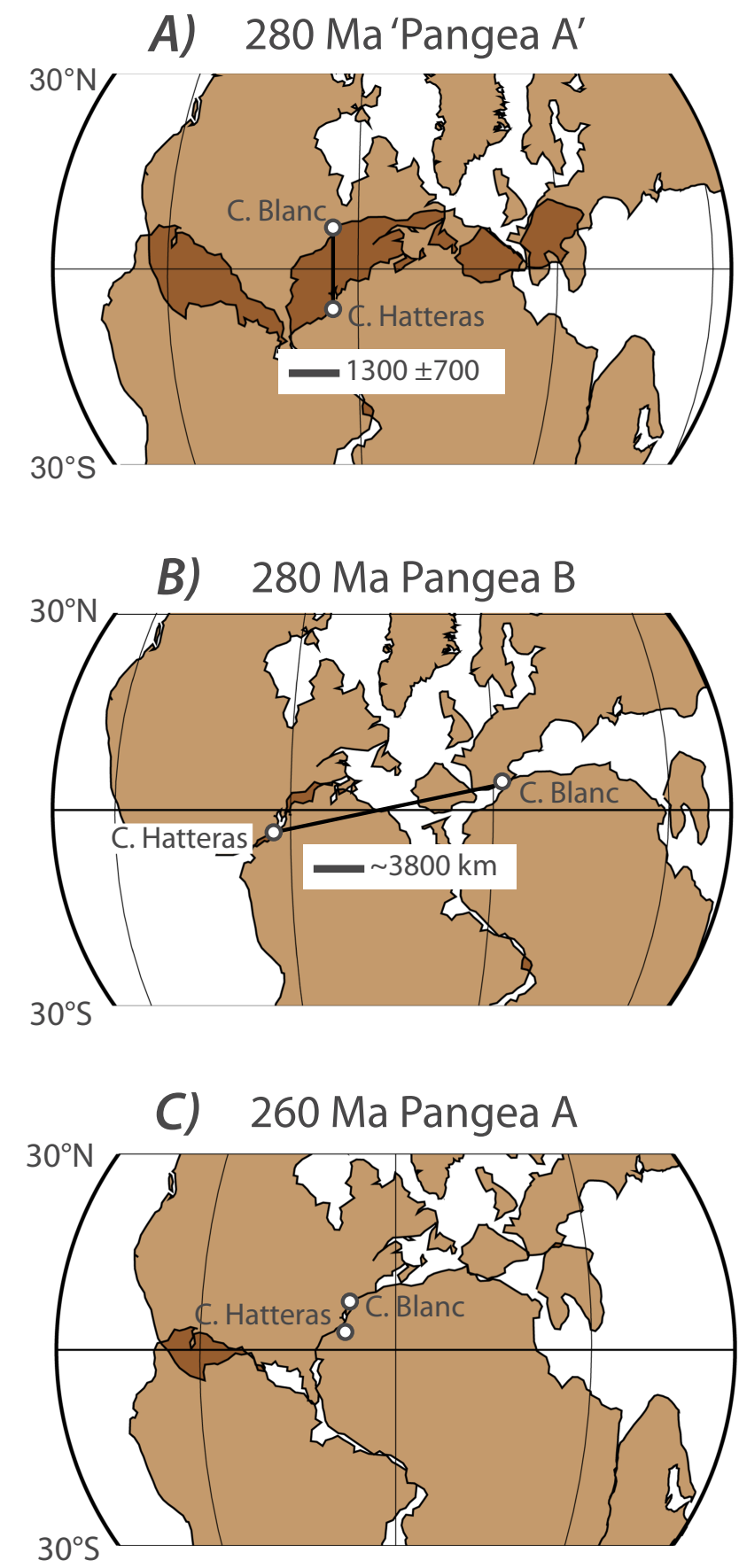

Fig. 5. Paleogeographic consequences of reconstructing Pangea according to different mean poles for Laurasia and Gondwana. A) Attempt at a Pangea Atype fit for the Early Permian using optimized 280 Ma mean poles (only igneous and E/I or I-corrected sedimentary results) for Laurasia and Gondwana (ID4 and ID22, Table 1), which causes a prohibitively large overlap in continental crust. B) Pangea B reconstruction for Early Permian that satisfies within A95s same poles as in (A) by sliding Gondwana eastward by about $35^{\circ}$ relative longitude. C) Pangea A-type reconstruction in Late Permian allowed within A95s by optimized 260 Ma mean poles (igneous and E/I or I-corrected sedimentary results) for Laurasia and Gondwana (ID1 and ID16, Table 1). Cape Hatteras locality on seaboard of eastern North America (C. Hatteras: presently $35.3^{\circ} \mathrm{N} 75.5^{\circ} \mathrm{W}$ ) and Cape Blanc locality on seaboard of NW Africa (C. Blanc: presently $21.0^{\circ} \mathrm{N}$ $17.0^{\circ} \mathrm{W}$ ) are shown for reference.

\subsection{Pangea reconstructions}

Pangea reconstructions based on our mean igneous and E/I or Icorrected sedimentary poles for Laurasia and Gondwana for $260 \mathrm{Ma}$, $280 \mathrm{Ma}$, and $310 \mathrm{Ma}$ are shown in Fig. 6. Pole data supporting the reconstructions for $260 \mathrm{Ma}$ (Late Permian; Fig. 6A) and 280 Ma (Early Permian; Fig. 6B) have been discussed above. Laurasia and especially Gondwana paleomagnetic data for $310 \mathrm{Ma}$ (Late Carboniferous) are fewer and more poorly grouped (Fig. 4, Table 1) and thus allow a less definitive assessment with regard to Pangea configurations. However, given the aforementioned conformance with a Pangea B configuration of the more robust Early Permian pole datasets, it seems logical to make Pangea B the null hypothesis for the Late Carboniferous, for which the 310 Ma mean igneous and E/I or I-corrected poles (ID8 for Laurasia and ID26 for Gondwana) are not inconsistent (Fig. 6C). It thus appears that together with its probable $330 \mathrm{Ma}$ (Early Carboniferous) antecedent (Fig. 6D; see also Fig. 18 in Torsvik et al. (2012)), Pangea B persisted for at least $55 \mathrm{Myr}(\sim 330 \mathrm{Ma}$ to $275 \mathrm{Ma})$ prior to its transformation to Pangea A. The temporal range of Pangea B overlaps with that of the LPIA, hinting at possible connections.

In contrast, Correia and Murphy (2020) recently argued that paleobotanical evidence for an Iberian-Appalachian connection in the Late Pennsylvanian favored Pangea A (and thus ruled out Pangea B). They assume that through the Paleozoic, Iberia occupied a position relative to North Africa similar to today's, reaching contiguity with eastern North America as a consequence of Variscan coalescence of Laurasia and Gondwana in a Pangea A geometry. Several studies of detrital zircon provenance and regional tectonostratigraphy have attempted to place Iberia (and other Armorican units) relative to the West African craton in the Neoproterozoic-Paleozoic, ranging from a position similar to today's (e.g., Diez Fernández et al., 2010; Pastor-Galán et al., 2013; Stephan et al., 2019), and hence more consistent with Pangea A sensu assumptions of Correia and Murphy (2020), to a position closer to the Africa-South America embayment (Linnemann et al., 2004) that we observe would be more compatible with Pangea B. The concept that Iberia as part of the Armorican domain was attached to Africa for much of the Paleozoic has, however, been questioned by Franke et al. (2019), who cite geological evidence pointing to the rifting of Armorican units (including Iberia) from peri-Gondwana in the Early Paleozoic, postdating the time range of nearly all of the zircon data included in the recent and comprehensive review of Stephan et al. (2019) and before main Variscan coalescence starting in the Devonian. The 'missing link' between Iberia and the Appalachians found by Correia and Murphy (2020) would thus no longer be able to resolve the Pangea A versus Pangea B controversy. On the other hand, we suggest that the apparent southward migration of the dry-climate adapted Lesleya flora over Pennsylvanian time shown in Fig. 4 of Correia and Murphy (2020) can be readily explained by northward drift of central Pangea B into the tropical arid belt (compare Fig. 6C and B).

\section{Changes in land area in equatorial humid belt}

The $\sim 3500-3800 \mathrm{~km}$ tectonic translation from Pangea B to Pangea A, which took place at inferred speeds comparable to India's convergence with Eurasia in the Late Cretaceous (Kumar et al., 2007), occurred obliquely within the equatorial humid belt. This had the effect of decreasing the land area in this optimal setting for silicate weathering as well as coal forests and mires. We assume the equatorial humid belt (precipitation exceeding evaporation) was nominally between $5^{\circ} \mathrm{S}$ and $5^{\circ} \mathrm{N}$ and whose latitudinal position was relatively insensitive to atmospheric $\mathrm{CO}_{2}$ concentration following Manabe and Bryan (1985) (Fig. 7A, B). More recent global climate modeling experiments confirm that the Hadley cells that control the position of the equatorial humid belt are indeed narrowly confined, within $10^{\circ}$ of the equator (Tabor and Poulsen, 2008). More pertinently, the present-day watershed $\mathrm{CO}_{2}$ consumption estimates of basaltic provinces of Dessert et al. (2003) 


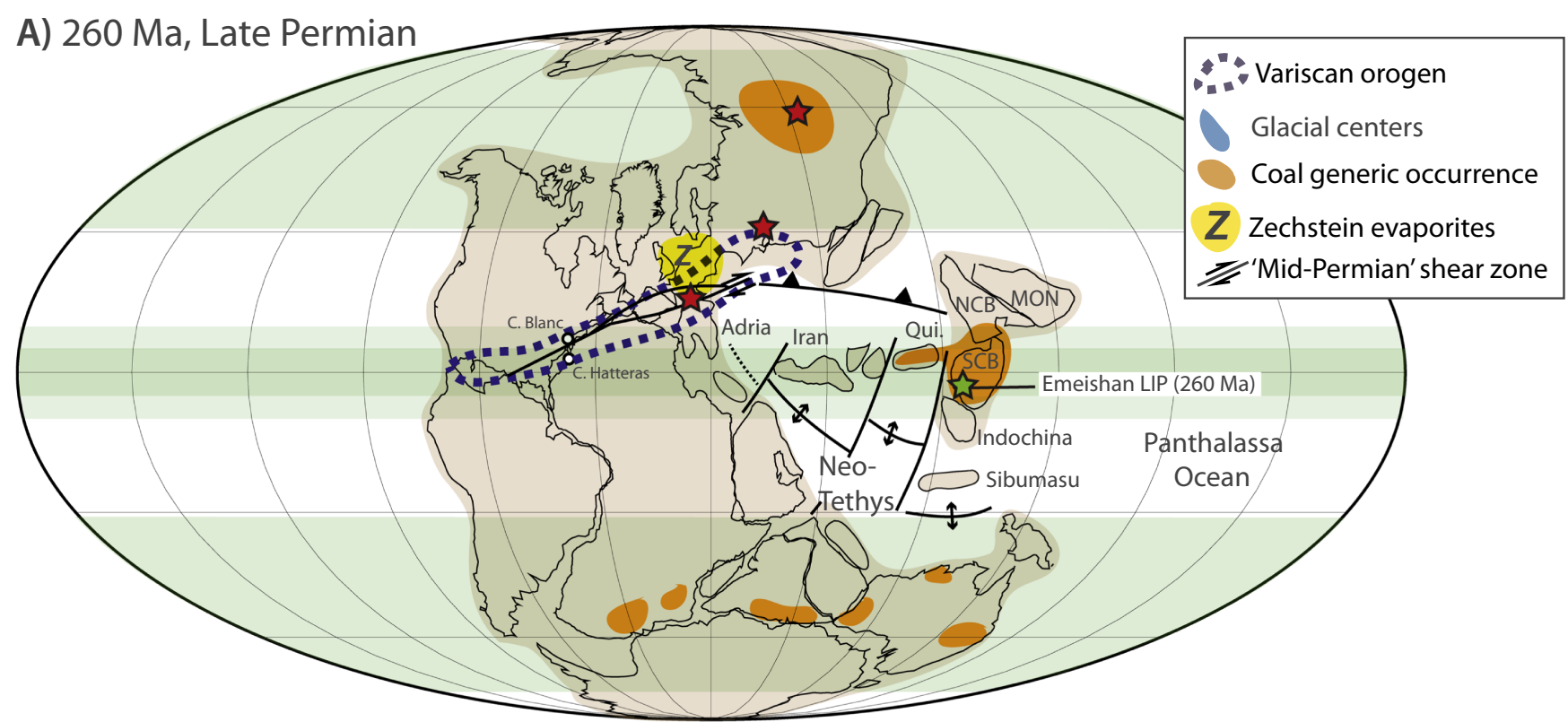

B) $280 \mathrm{Ma}$, Early Permian

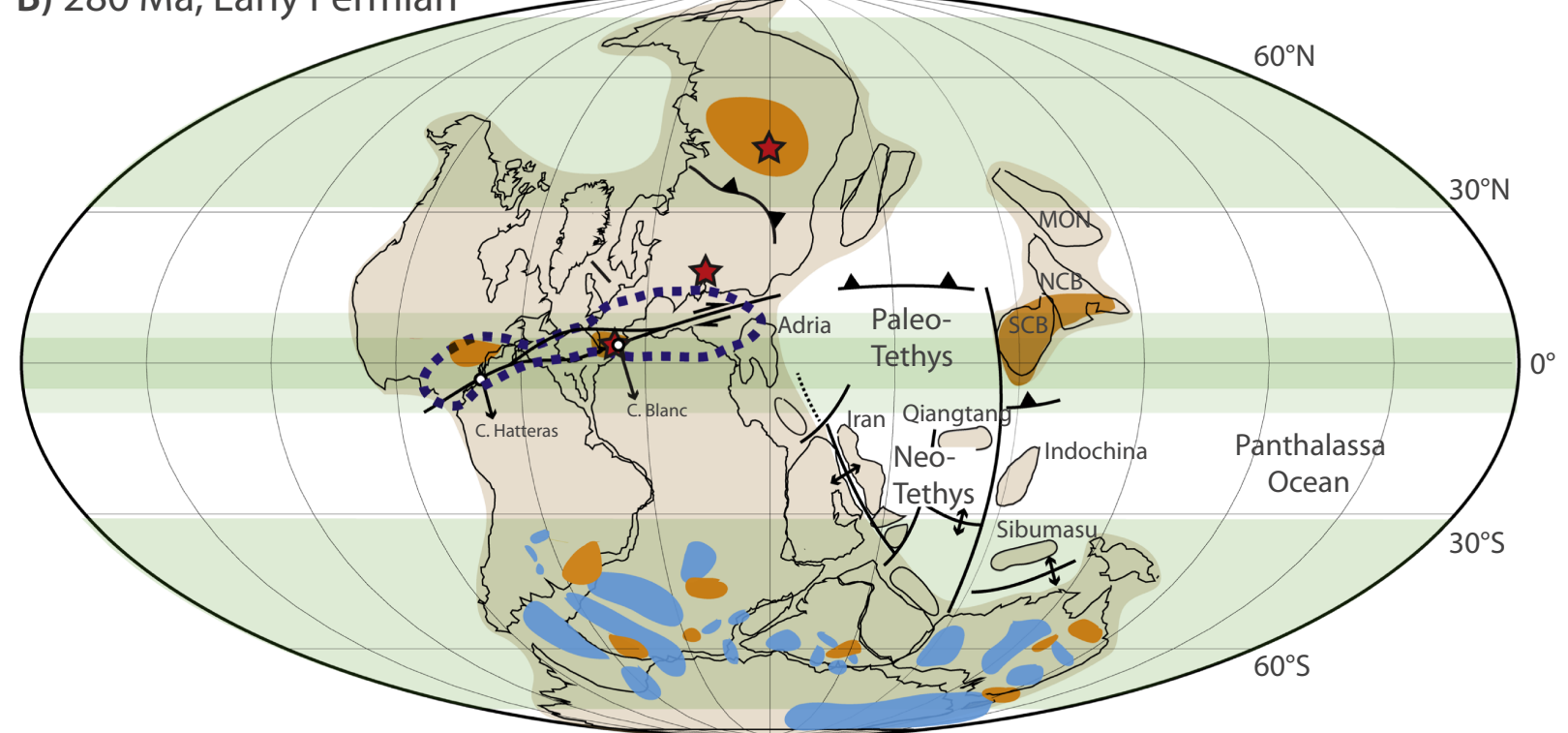

C) $310 \mathrm{Ma}$, Late Carboniferous

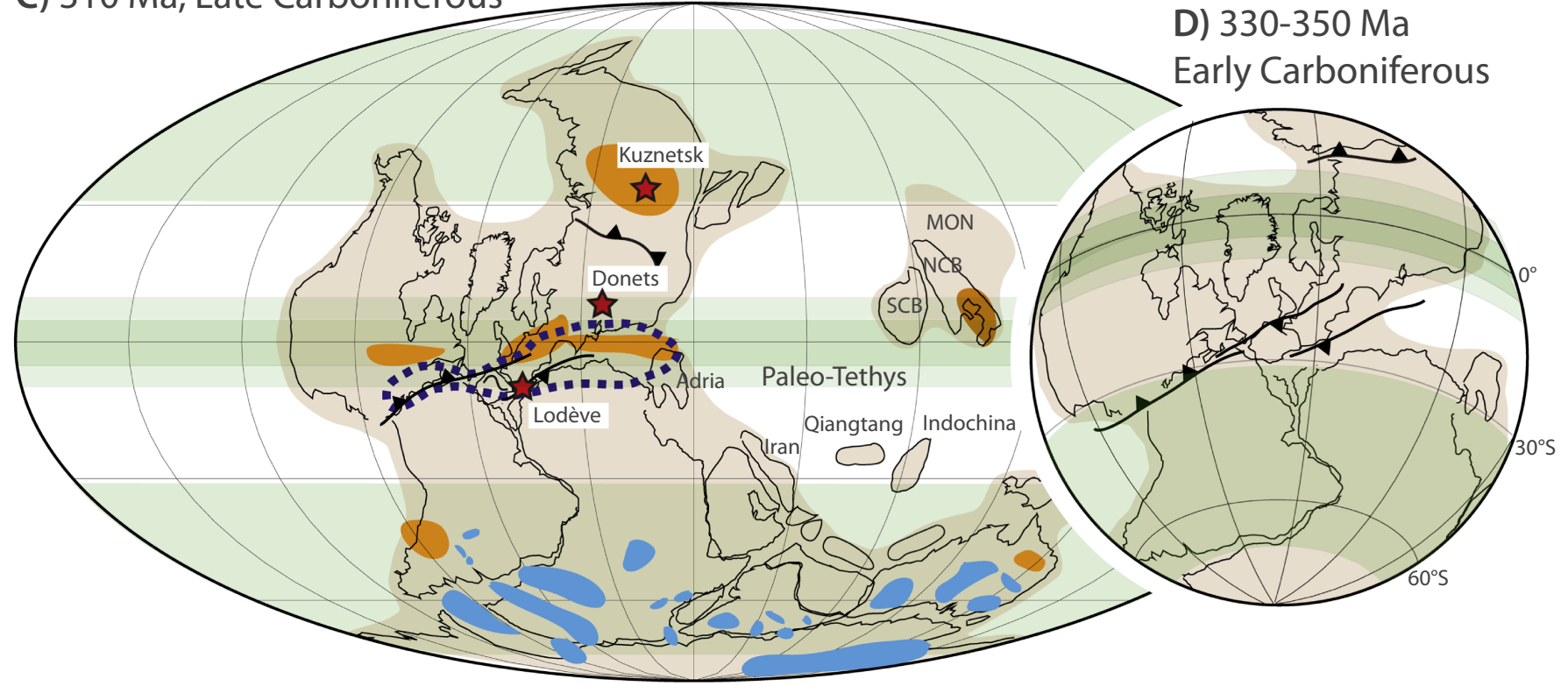




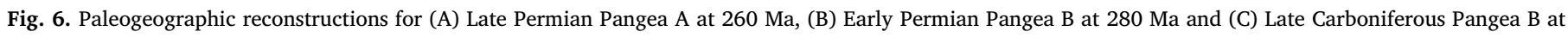

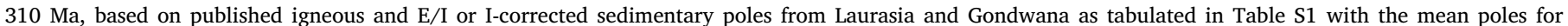

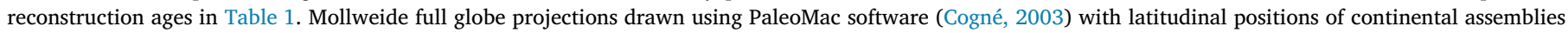

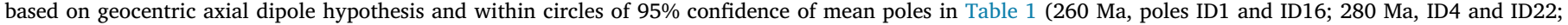

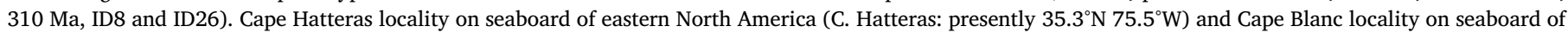

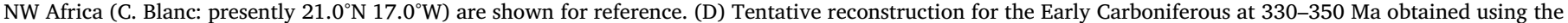

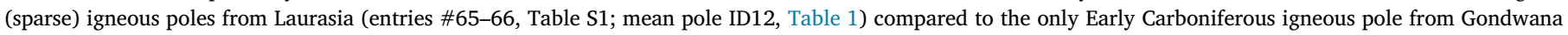

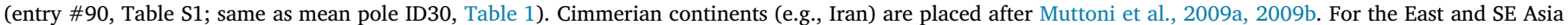

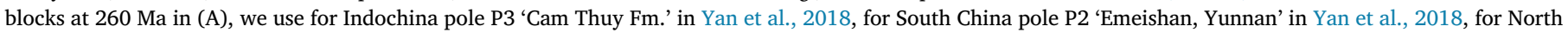

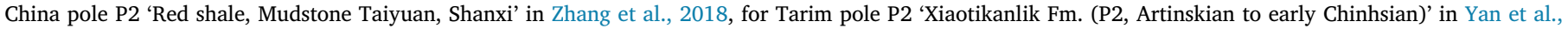

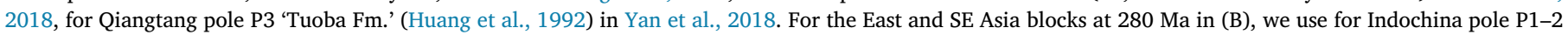

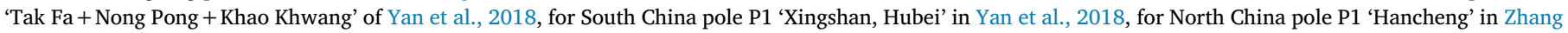

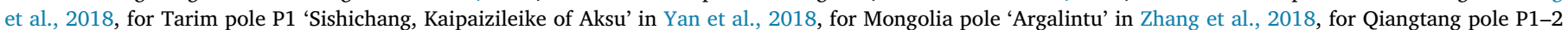

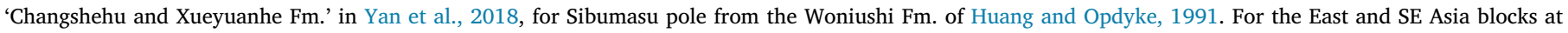

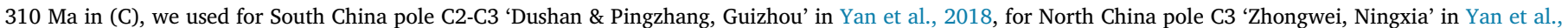

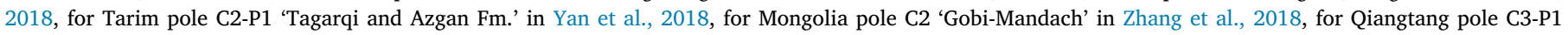

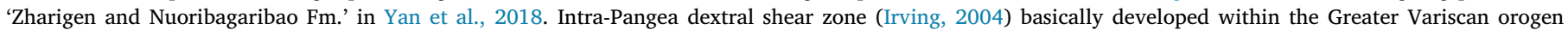

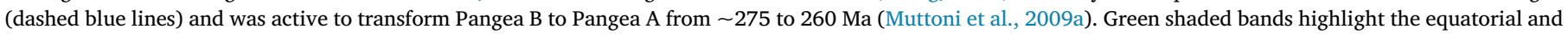

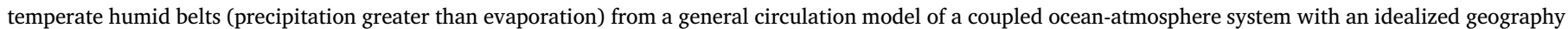

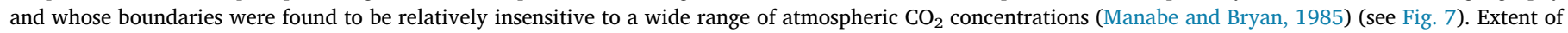

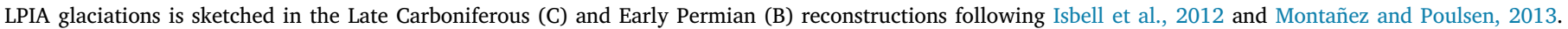

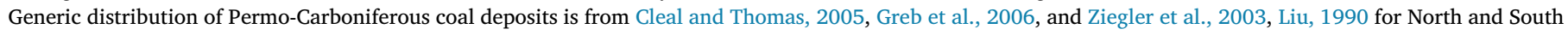

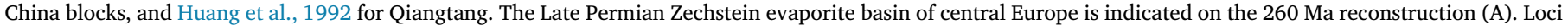

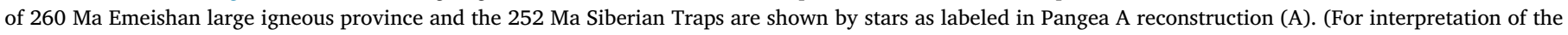
references to color in this figure legend, the reader is referred to the web version of this article.)

show a very high value for SE Asia straddling the equator, markedly decreased values for localities between $10^{\circ}$ to about $30^{\circ}$ latitude like Central America, Parana and Deccan, and low values at higher latitudes in places like the Cascades, Patagonia and Siberia (Fig. 7C). This pattern reflects the importance of water availability (net precipitation) to account for intense weathering close to the equator, much reduced but highly variable weathering because of monsoonal rains in the tropical arid belt to about $\pm 30^{\circ}$ latitude, and the overriding effects of lower annual temperatures in the temperate humid belt poleward of $\pm 30^{\circ}$ latitude to account for the consistently low $\mathrm{CO}_{2}$ consumption rates found in those mid- to high latitude locales.

We estimate from the paleogeographic reconstructions (Fig. 6) that the Pangea continental area within the $5^{\circ} \mathrm{S}$ to $5^{\circ} \mathrm{N}$ latitude band decreased from $\sim 13$ million square kilometers $\left(\mathrm{Mkm}^{2}\right)$ for Pangea B in the Early Permian (and a similar area in the Late Carboniferous) to $\sim 9$ $\mathrm{Mkm}^{2}$ for Pangea A in the Late Permian. This represents a $\sim 30 \%$ decrease in land area, or a reduction in land area from around $30 \%$ to around $20 \%$ of the total surface area in the $5^{\circ} \mathrm{S}-5^{\circ} \mathrm{N}$ latitudinal belt (44.5 $\mathrm{Mkm}^{2}$, or $8.7 \%$ of Earth's $510 \mathrm{Mkm}^{2}$ total surface area) with a complementary $13 \%$ increase $\left(31.5\right.$ to $35.5 \mathrm{Mkm}^{2}$ ) in oceanic area that incidentally usually has lower surface albedo than most land areas. Somewhat smaller relative changes in land area are estimated for the $10^{\circ} \mathrm{S}$ to $10^{\circ} \mathrm{N}$ latitude band: $\sim 21.5 \mathrm{Mkm}^{2}$ for Pangea $\mathrm{B}$ and $\sim 18 \mathrm{Mkm}^{2}$ for Pangea A (without the China-Cimmerian blocks), a decrease from $\sim 24 \%$ to $\sim 20 \%$ in land area in the $\pm 10^{\circ}$ latitude band $\left(88.6 \mathrm{Mkm}^{2}\right.$, or $17.4 \%$ of Earth's total surface area).

The various East Asia (e.g., South and North China) and Cimmerian (e.g., Iran) continental blocks may account for an additional 1-3 $\mathrm{Mkm}^{2}$ of land area within $5^{\circ}$ of the equator but their precise locations with time are at present difficult to estimate. Paleomagnetic data show that the North and South China cratons (NCB and SCB, respectively) were close to the equatorial belt over much of the Carboniferous and Permian, which we register as a more or less constant $1-2 \mathrm{Mkm}^{2}$ land presence there including during the Pangea B to Pangea A transformation. Moreover, the NCB and SCB become important venues in the Permian for low latitude coal mires (Cleal and Thomas, 2005), which largely ceased to form in the Euramerica part of equatorial Pangea after the Late Carboniferous (Ziegler et al., 2003) (Fig. 6). Other uncertainties concern the size of the Cimmerian microcontinental blocks (e.g., Iran, Qiangtang [Tibet], but also the less known Afghanistan and Karakorum terranes), which rifted off the northern margin of
Gondwana during the opening of the Neo-Tethys in the Early Permian, and the timing of their drift across the equatorial humid belt in the Middle to Late Permian (Muttoni et al., 2009a, 2009b). We budget 1.5 $\mathrm{Mkm}^{2}$ for the Cimmerian microcontinents and place them in the equatorial humid belt just after the transformation of Pangea B to Pangea A, which would counterbalance some of the associated land area reduction in central Pangea. A possible scenario is that the total (Pangea plus East Asia) land area within the $5^{\circ} \mathrm{S}$ to $5^{\circ} \mathrm{N}$ latitude band was $\sim 14 \mathrm{Mkm}^{2}$ for the Early Permian and $\sim 12 \mathrm{Mkm}^{2}$ for the Late Permian, in which case the reduction of equatorial land area would be a more modest $\sim 2 \mathrm{Mkm}^{2}$ or $14 \%$.

\section{Geological landscape across Pangea $B$ and its transformation to Pangea A}

Pangea B and its eventual transformation to Pangea A were also accompanied by latitudinal and vertical movements in the evolution of the Greater Variscan orogen that played important roles in controlling $\mathrm{CO}_{2}$ drawdown from silicate weathering as well as organic carbon burial. In the Late Carboniferous-Early Permian, the orogen was associated with crustal thinning and localized subsidence with formation of intra-montane (intra-orogenic) basins, and extensive magmatism (Franke, 2014). This tectonic pattern was associated with the oblique convergence of Laurasia and Gondwana (with dextral shearing sensu Arthaud and Matte (1977)) starting by the Early Carboniferous and continuing into the Late Carboniferous-Early Permian. Topographic relief may have been focused along shear zones (Elter et al., 2020) or exhumed crystalline massifs (Iberian, Armorican, Central, and Bohemian; Fig. 8A) but contra the high altitude plateau model of Goddéris et al. (2017), the overall signature was that of a horst-and-graben type orogen (Zeh and Brätz, 2004) with widespread extension and magmatism (Schaltegger and Corfu, 1995), pull-apart basin formation (Elter et al., 2020) and generally low relief (Franke, 2014). In the Variscan foreland and cratonic basins of the North Sea, the occurrence of marine horizons within the Late Carboniferous coal-bearing sequences is evidence of generally very low elevations in these peripheral regions of the orogen (Glennie, 1986); similarly, the presence of benthic foraminifera in the thick volcanoclastic succession filling the Early Permian intramontane Collio Basin of the Southern Alps indicates it was at least partly at sea level (Sciunnach, 2001).

Elevations were thus probably not all that high even though the Late 

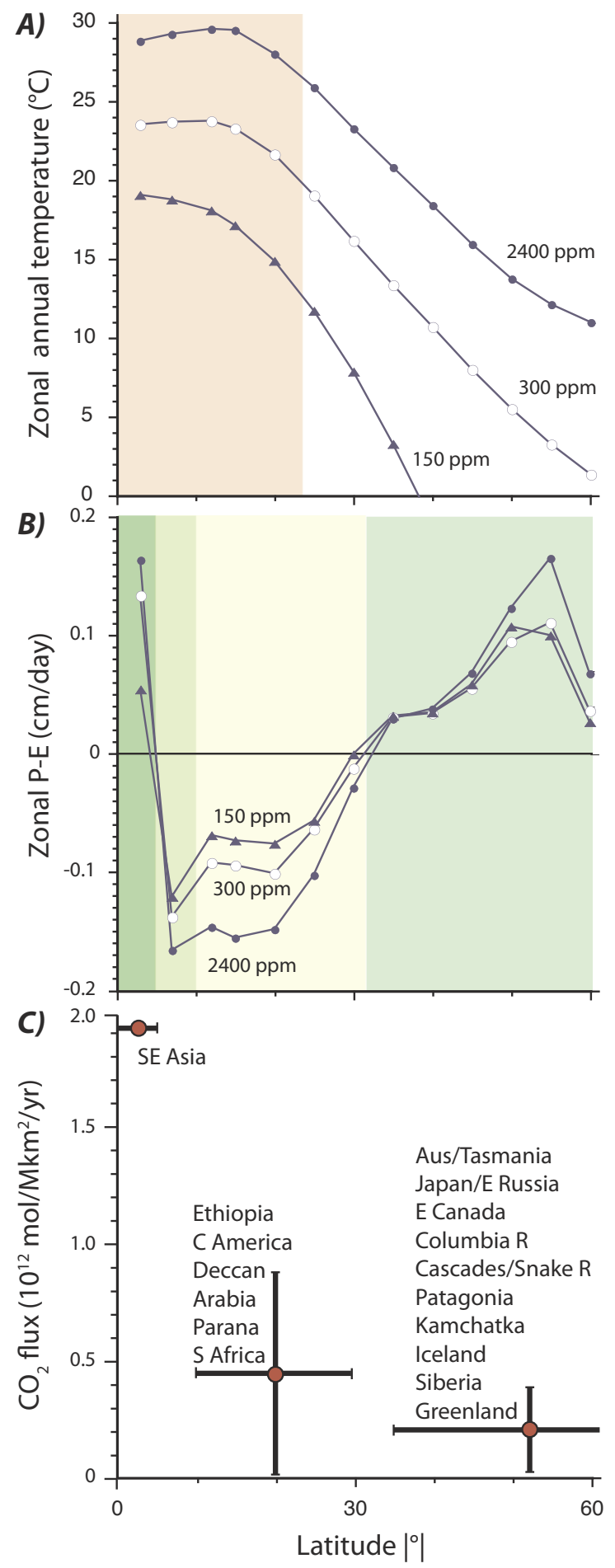

Carboniferous-Early Permian geological landscape during the time of Pangea B was nonetheless dominated by exposures of deformed and metamorphosed Variscan crust dissected by normal faults that delimited troughs filled with variable amounts of volcanics, continental (e.g., lacustrine, coal-bearing) and even marine sediments (Timmerman, 2004) (Fig. 8A). This can be observed across the Southern Alps where the stratigraphy of the Permian is particularly well exposed (Fig. 8B; Cassinis and Perotti, 2007; see also Muttoni and Kent, 2019a). The largest Late Carboniferous-Early Permian extensional basins, however, developed in central-northern Europe and were filled by Late
Fig. 7. Mean annual temperature (A) and net annual moisture (precipitation minus evaporation, P-E) (B) versus absolute latitude for pre-industrial (300 ppm), half pre-industrial (150 ppm) and eight times pre-industrial $(2400 \mathrm{ppm}) \mathrm{pCO}_{2}$ from a global climate model with idealized geography (Manabe and Bryan, 1985) compared to $\mathrm{CO}_{2}$ consumption flux (C) for various modern watershed areas in basalts (from Table 2 in Dessert et al. (2003)). The climate model and weathering data suggest that continental silicate weathering is likely to be most intense in the tropics (light orange shading in A) within the equatorial humid belt extending $5^{\circ}$ to perhaps $10^{\circ}$ (green and lighter green shading in B) from the equator, but much less intense in the tropical arid belt to $\sim 30^{\circ}$ latitude due to decreased moisture and in the temperate humid belt (medium green shading in B) and higher latitudes due to lower surface temperatures. The high silicate weathering region was assumed more generously to extend over the annual migration of the modern intertropical convergence zone producing a rain belt extending to $\pm 20^{\circ}$ latitude by Jagoutz et al. (2016) or $\pm 10^{\circ}$ to $20^{\circ}$ latitude by Macdonald et al. (2019). (For interpretation of the references to color in this figure legend, the reader is referred to the web version of this article.)

Carboniferous sediments and voluminous Lower Rotliegend volcanics with a regional pulse in the Early Permian (Stephenson et al., 2003; Heeremans et al., 2004). The more elevated portions of the orogen were presumably localized in the Iberian, Armorican, Central, and Bohemian Massifs (Fig. 7A) as well as in the Alleghenian collision zone in Mexico, Florida, and the Carolinas (Murphy et al., 2011) and are constituted by complex suites of Paleozoic rocks including felsic and intermediate (meta)magmatic units and mafic complexes with (meta)basalts and (meta)gabbros interpreted as ophiolites related to the consumption of the Rheic Ocean (see also below).

In the Middle to Late Permian, during and just after the Pangea B to Pangea A transformation, topographic relief was further reduced as subsidence and sediment accommodation space diminished and the basins were overlain by extensive blankets of continental siliciclastic sequences. This depositional pattern is observed in the Southern Alps (Verrucano-Valgardena sandstones, Fig. 8A,B; Cassinis and Perotti, 2007) and elsewhere in Europe, where the Upper Rotliegend sandstones expanded laterally much beyond the former Early Permian troughs (Heeremans et al., 2004) as observed for example in the Polish Basin (Stephenson et al., 2003) (Fig. 8A,C). The Greater Variscan geological landscape of equatorial Pangea in North America and Europe thus evolved from being characterized by highly subsiding, sometimes coalrich basins (coal deposition occurred mainly in the Variscan foreland but also in intra-orogenic basins) bounded by crystalline-metamorphic massifs with ophiolites in the Late Carboniferous-Early Permian, to being generally flatter and largely covered by siliciclastics with scant coal preservation by the Late Permian. It is also worth noting that the orogen as the locus of bedrock exposures was near equatorial in the Late Carboniferous and Early Permian, and drifted substantially out of the prime equatorial weathering zone by the Late Permian after transformation of Pangea B to Pangea A (Fig. 8A; see also Fig. 6).

\subsection{Changes in temporal and geographic distribution of coal basins}

The Greater Variscan Orogen was the locus of major coal basins of Europe and eastern North America (Cleal and Thomas, 2005; Greb et al., 2006; Rees et al., 2002; Tabor and Poulsen, 2008; Ziegler et al., 2003) as it drifted into the equatorial humid belt in the Late Carboniferous (Fig. 6C). As stressed by Nelsen et al. (2016), '[e]xtensive foreland and cratonic basins, formed in association with the Pennsylvanian [Late Carboniferous] - Permian coalescence of Pangea and were positioned in the humid equatorial zone, ensuring the occurrence of both the subsidence requisite for long-term preservation of organic deposits and the climate necessary for promoting high water tables and biological productivity.' These tectonically and paleogeographically controlled conditions that characterize the Greater Variscan Orogen (Fig. 8A) were what permitted high burial rates of organic carbon that 


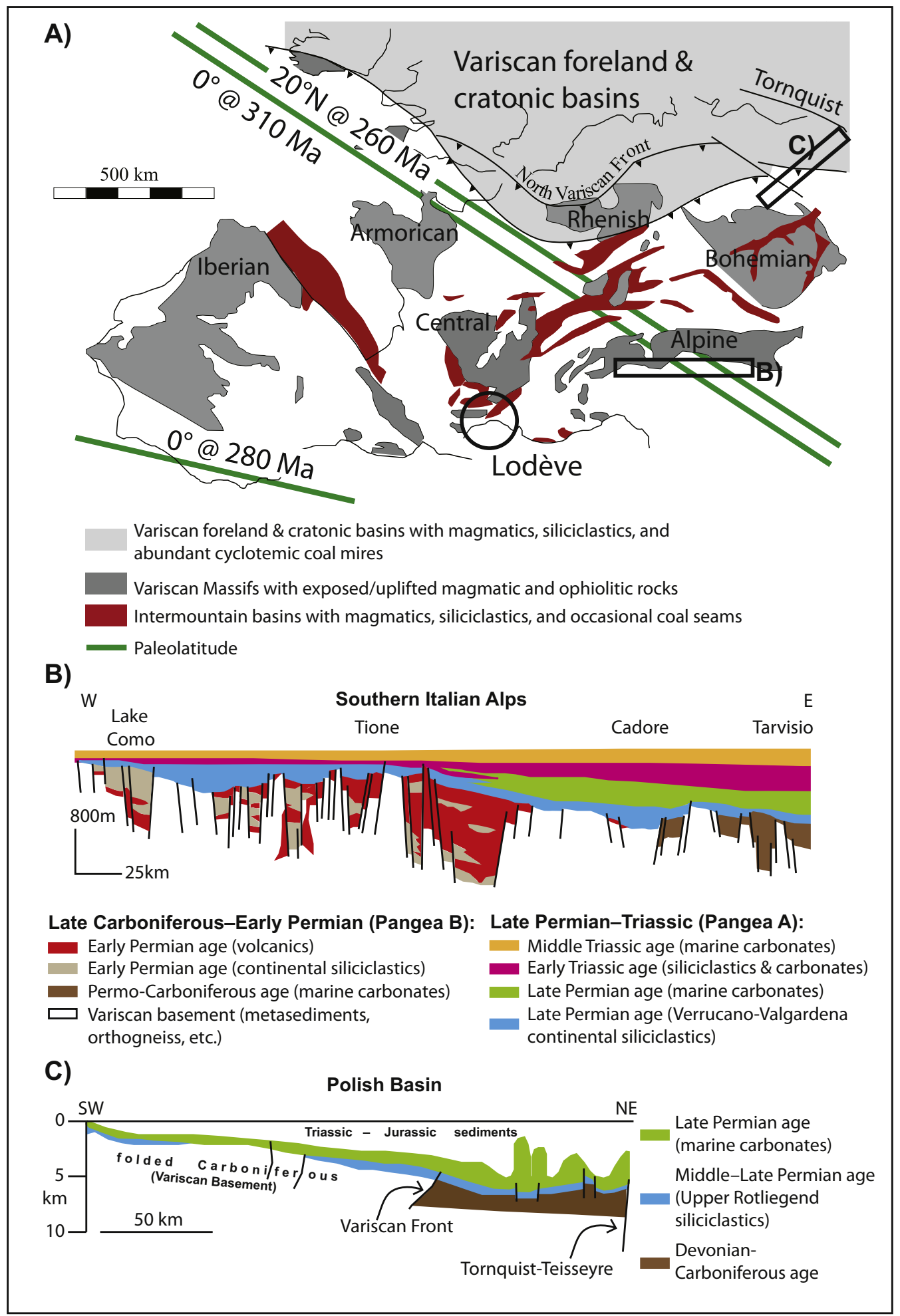

Fig. 8. A) General geologic landscape of Europe for the time of Pangea B (Late Carboniferous-Early Permian) (redrawn from Pochat and Driessche, 2011; Timmerman, 2004; Arenas et al., 2016) showing exposed/uplifted Variscan massifs with magmatic and ophiolitic rocks of variable metamorphic grade (dark gray), which represent preferred loci of silicate weathering, and foreland and intra-orogenic subsiding basins, which represent preferred loci of organic carbon burial. Also indicated are reference paleolatitudes from our paleomagnetic-based paleogeographic reconstructions at 310 and $280 \mathrm{Ma}\left(0^{\circ}=\right.$ equator), and $260 \mathrm{Ma}\left(20^{\circ} \mathrm{N}\right)$ marking the persistent northward drift of Pangea before (310 and $280 \mathrm{Ma}$ ) and after (260 Ma) its transformation from Pangea B to Pangea A. B) Transect across the Southern Italian Alps (redrawn after Cassinis and Perotti, 2007) and C) transect across the Polish Basin (redrawn after Stephenson et al., 2003) showing the general evolution of the Variscan Orogen from a horst-graben type morphology in the Late Carboniferous-Early Permian, characterized by uplifted basement shoulders bounding subsiding basins, to a beveled morphology with less relief in the Late Permian when Upper Rotliegend and similar siliciclastics prograded over much of the continent, suturing the orogen and effectively reducing silicate weathering and organic carbon burial in reduced accommodation-space basins. 


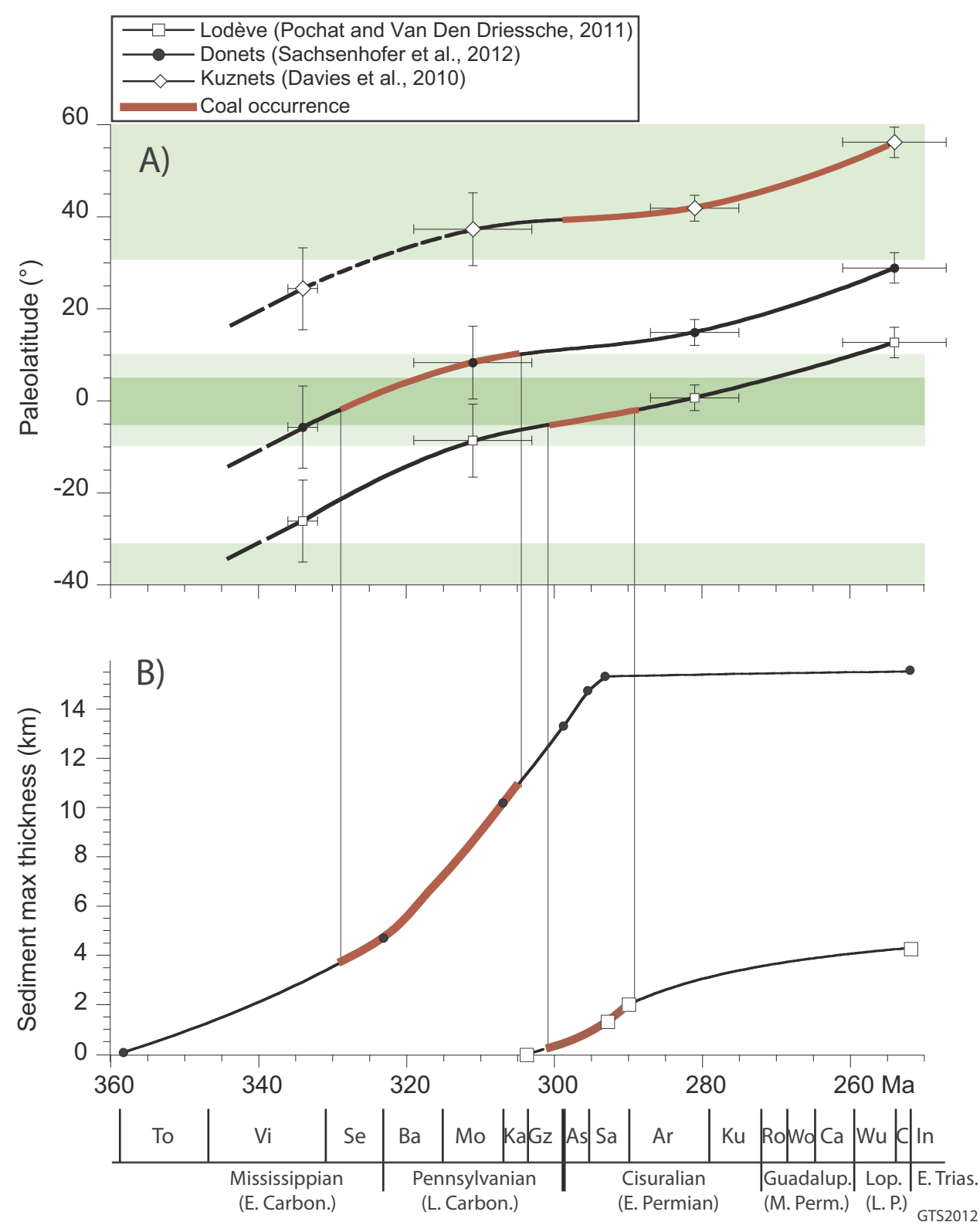

Fig. 9. Latitudinal drift and depositional history of selected Late Paleozoic coal basins. A) Paleolatitude (this study) versus age (ported to Gradstein et al. (2012) timescale) of sedimentary successions in Graissessac-Lodève (France; Pochat and Driessche, 2011), Donets (Ukraine; Sachsenhofer et al., 2012), and Kuznet (Siberia; Davies et al., 2010; Reichow et al., 2009) basins including nominal time windows of coal occurrence. B) Sediment thickness versus age of Graissessac-Lodève (Pochat and Driessche, 2011) and Donets (Sachsenhofer et al., 2012) basins showing the reduction in sedimentation (accommodation space) from the Late Carboniferous-Early Permian to later in the Permian. Coal burial occurs when subsidence and zonal climate conspire favorably to maximize sediment accumulation. most probably contributed to the drawdown of atmospheric $\mathrm{CO}_{2}$ that helped promulgate the LPIA (Feulner, 2017).

Coal deposits across equatorial North America and Europe decreased dramatically in areal extent from the Late Carboniferous (Fig. 6C) to the Early Permian (Fig. 6B) and virtually disappeared by the Middle to Late Permian (Fig. 6A) when the loci of tropical coal deposition with Euramerica flora shifted across the Tethys to coal deposits with Cathaysian flora of the East Asian blocks (e.g., Cleal and Thomas, 2005; Greb et al., 2006; Liu, 1990; Rees et al., 2002; Shao et al., 2012; Tabor and Poulsen, 2008; Wang et al., 2012; Ziegler et al., 2003) (see also Fig. 1). The virtual disappearance of equatorial coals in North America and Europe could be related, in part, to the moderate northward motion of the Greater Variscan orogen out of the equatorial humid belt and into the arid tropics, which eventually resulted in evaporite (Zechstein) deposition over central Europe by the Late Permian (Fig. 6A). Another factor was probably a preservation effect due to diminished accommodation space of the previously highly subsiding and coal-rich Late Carboniferous basins. For example, the Graissessac-Lodève Basin in southern France (Pochat and Driessche, 2011) has buried coal mires in the Late Carboniferous-Early Permian when it dwelled at paleolatitudes close to the $5^{\circ} \mathrm{S}-5^{\circ} \mathrm{N}$ equatorial humid belt (Fig. 9A). At this same (Late Carboniferous-Early Permian) time, the basin was characterized by relatively high sediment accumulation rates that more than halved by the Late Permian (Fig. 9B). Accumulation of coal in the Graissessac-Lodève basin thus occurred in the Late Carboniferous-Early Permian when sediment accumulation rates were the highest and the basin was closest to the equator. Similar observations can be made for the much larger Donets basin of the Ukraine (Sachsenhofer et al., 2012) where the timing of coal accumulation is confined to the Late Carboniferous when the basin drifted northward across the equatorial humid belt (Fig. 9A) while experiencing the relatively highest accumulation rates (Fig. 9B).

In this respect, the interpretation of aridification over equatorial Pangea from the Carboniferous to the Permian (e.g., Tabor and Poulsen, 2008; Ziegler et al., 2003) is worth reconsideration (Pochat and Driessche, 2011). The generalized transition from Late Carboniferous-Early Permian black shale-coal deposition to Late Permian red bed (and no coal) accumulation was more likely a natural outcome of the way these basins evolved and became filled during the Permian along with their northward drift into the boreal tropical arid belt rather than 
due to global changes in climate such as monsoons (e.g., Kutzbach and Gallimore, 1989). The debate is yet to be settled (Michel et al., 2015) but we would note that coal forests persisted into the Late Permian over the equatorial East Asia continental blocks (Fig. 6A; Greb et al., 2006; Rees et al., 2002) indicating no aridification in these equatorial basins where subsidence was evidently not a limiting factor for coal preservation (Wang et al., 2011).

Unlike the European-North American and East Asia coals that are equatorial, the Siberian coals with Angaran flora are temperate. Moreover, the chronostratigraphy of the Kuznets basin (one of the largest coal basins of Siberia) can be interpreted to show that these areas of Siberia had to drift out of the northern tropical arid belt and into the boreal temperate humid belt before coals could accumulate (Davies et al., 2010) (Fig. 9A). Temperate latitude coals of Gondwana flora also developed in the Southern Hemisphere, sometimes interspersed with glacial deposits, but always outside (more southerly of) the austral tropical arid belt (Griffis et al., 2019; Montañez and Poulsen, 2013) (Fig. 6). Temperate latitude coals then dominate the Mesozoic and Cenozoic.

\section{Changes in $\mathrm{CO}_{2}$ consumption from silicate weathering and organic carbon burial}

Although it is difficult to directly inventory organic carbon burial and associated $\mathrm{CO}_{2}$ consumption due to coal generation across the Greater Variscan orogen and elsewhere, the global contribution of organic carbon burial (marine and terrestrial; Magaritz and Holser (1990)) can be estimated as the fraction of total carbon consumption $\left(\mathrm{f}_{\text {org }}\right)$ from marine carbonate $\delta^{13} \mathrm{C}_{\text {carb }}$ data according to:

$\mathrm{f}_{\text {org }}=\left(\delta^{13} \mathrm{C}_{\text {carb }}-\delta^{13} \mathrm{C}_{\text {out }}\right) /\left(\delta^{13} \mathrm{C}_{\text {carb }}-\delta^{13} \mathrm{C}_{\text {org }}\right)$

where $\delta^{13} \mathrm{C}_{\text {out }}$ is the nominal riverine or long-term volcanic carbon isotopic value of $-5 \%$ and $\delta^{13} \mathrm{C}_{\text {org }}$ is contemporaneous organic carbon with an assumed photosynthetic carbon fractionation of $-25 \%$ (Caves et al., 2016; Hayes et al., 1999; Kump and Arthur, 1999). We interpolated the $\mathrm{f}_{\text {org }}$ data with a LOWESS function (Fig. 1D) although it should be noted that the $\delta^{13} \mathrm{C}_{\text {carb }}$ data of Veizer et al. (1999) used to calculate $f_{\text {org }}$ are severely unevenly distributed in the Carboniferous-Permian time interval (1259 observations from 360 to 295 Ma but only 122 from 295 to 250 Ma where the mean is consequently dashed in Fig. 1D).

The $\delta^{13} \mathrm{C}_{\text {carb }}$ data of Veizer et al. (1999) were plotted by Goddéris et al. (2017) who characterized them as mostly showing uniform high values from 360 to 260 Ma. However, we call attention to the significant increase in $\mathrm{f}_{\text {org }}$ in the densely populated part of the record from around 0.25 at $330 \mathrm{Ma}$ to 0.32 at $320 \mathrm{Ma}$ and peaking at 0.35 in the Moscovian $(\sim 310 \mathrm{Ma})$, a pattern that parallels the increase in coal forest area (Fig. 1C) and in glacial frequency (Fig. 1B). The increase in $\mathrm{f}_{\text {org }}$ also broadly coincides with a peak at around $310 \mathrm{Ma}$ in seawater ${ }^{87} \mathrm{Sr} /{ }^{86} \mathrm{Sr}$ values as a proxy for higher continental silicate weathering (Fig. 1E). The available $\delta^{13} \mathrm{C}_{\text {carb }}$ data for the earliest Permian still have relatively high positive values (pointing to high $\mathrm{f}_{\text {org }}$ ), which might reflect enhanced organic carbon burial in equatorial coal mires in the Far East (Fig. 1C) or perhaps in the oceans (Chen et al., 2018), for example, the Permian Basin of West Texas (Anonymous, 2018), but the data are too sparse to determine any systematic pattern of change in organic carbon burial for the rest of the Permian (younger than $\sim 295 \mathrm{Ma}$ ). In any case, increased organic carbon burial may have amplified drawdown of $p \mathrm{CO}_{2}$ from silicate weathering $\mathrm{CO}_{2}$ consumption, perhaps from higher input of nutrients like phosphorus (Schrag et al., 2002), to levels below the glacial threshold in the Late Carboniferous-Early Permian (Fig. 1F).

More tractable to evaluate is $\mathrm{CO}_{2}$ consumption from continental silicate weathering. The modeling by Goddéris et al. (2017) estimated the contribution to global $\mathrm{CO}_{2}$ consumption from silicate weatherability of an initially highly elevated Greater Variscan Orogen in five time slices. From a null amount at $350 \mathrm{Ma}$ at its nascency, the Greater Variscan Orogen contribution to global $\mathrm{CO}_{2}$ consumption peaked at $35 \%$ at 308 Ma from the effects of presumed peak altitudes of $5000 \mathrm{~m}$ with steep slopes, and decreased to about $11 \%$ at 272 Ma with maximum altitudes of $2000 \mathrm{~m}$ when thicker saproliths started to form. A Pangea A-type configuration was used for all these time slices. If instead a more appropriate Pangea B configuration is used for these time slices and all else kept the same, the addition of $\sim 4 \mathrm{Mkm}^{2}$ continental area in the equatorial humid belt ought to have made $\mathrm{CO}_{2}$ consumption proportionately higher by $\sim 57 \%$ at $308 \mathrm{Ma}$ and decreasing to $\sim 18 \%$ at $272 \mathrm{Ma}$, which was then further reduced by $\sim 30 \%$ because of the proportionate decrease in equatorial continental area resulting from the transformation from Pangea B to Pangea A by 260 Ma. This comparison assumes a similar areal distribution of weatherable rock types, which we attempt to delineate for our case.

We estimate that the Greater Variscan orogen delineated by Golonka (2002) was about $7.5 \pm 1 \mathrm{Mkm}^{2}$ in extent (Fig. 2) and, by inspection of Fig. 6 , that about $1 / 2$ of its footprint $\left(3.75 \pm 0.5 \mathrm{Mkm}^{2}\right)$ resided within the equatorial humid belt $\left(5^{\circ} \mathrm{S}\right.$ to $\left.5^{\circ} \mathrm{N}\right)$ at any given time, first its eastern sector in the Late Carboniferous, then its western sector in the Early Permian as Pangea B drifted to the north. By the Late Permian, only about $1 / 3\left(2.5 \pm 0.33 \mathrm{Mkm}^{2}\right)$ of the orogen (its western part) still resided in the equatorial humid belt as Pangea (now transformed to the A-type configuration) continued drifting northward. We assume as a gross estimate that the crystalline exposures potentially subject to silicate weathering were concentrated in the Variscan crystalline massifs (e.g., Iberian, Bohemian, Central, Armorican, Fig. 8A; see also Fig. 2 in Murphy and Gutierrez-Alonso (2008)) that were locally exhumed (e.g., Zeh and Brätz, 2004; Corsini and Rolland, 2009; Pfeifer et al., 2018) relative to the surrounding lower relief orogen (Franke, 2014). These massifs are composed of (i) silicate rocks such as Carboniferous-Early Permian felsic and intermediate magmatic rocks as well as basalts and gabbros pertaining to earlier Paleozoic ophiolitic suites and their derived metamorphic products such as orthogneisses, granitoids, metagabbros, and (ii) $\mathrm{CaO}$ and $\mathrm{MgO}$-poor lithologies such as Carboniferous-Permian non-metamorphic quartzofeldspathic sediments as well as Devonian-Carboniferous metasediments of various composition (Fig. 8B,C and also Pfeifer et al., 2018; Pochat and Driessche, 2011).

We consider three scenarios in which the areal percentage of the Greater Variscan Orogen was constituted by exhumed and weatherable silicate rocks of mixed lithology (granitic-gneissic-basaltic) in the various crystalline massifs that amounted to $30 \pm 5 \%, 50 \pm 5 \%$, and $70 \pm 5 \%$. In assigning $\mathrm{CO}_{2}$ consumption from silicate weathering, we note that Dessert et al. (2003) found that weathering of $\mathrm{CaO}$ and $\mathrm{MgO}-$ rich mafic rocks that are exposed under optimal temperature and runoff conditions typical of the equatorial humid belt may consume anywhere from $84.5 \mathrm{t} \mathrm{CO}_{2} / \mathrm{yr} / \mathrm{km}^{2}$ ( $\mathrm{t}=$ tonne, $10^{3} \mathrm{~kg}$ ) as observed for modern SE Asia in toto (Fig. $7 \mathrm{C}$ ) to $282 \mathrm{t} \mathrm{CO}_{2} / \mathrm{yr} / \mathrm{km}^{2}$ as observed for the modern island of Java alone, suggesting a gross average of $100 \pm 25 \mathrm{t} \mathrm{CO}_{2} / \mathrm{yr} /$ $\mathrm{km}^{2}$. Effective $\mathrm{CO}_{2}$ consumption from silicate weathering of intermediate rocks is much lower, for example, a granodiorite watershed in Puerto Rico with a high runoff $(\sim 360 \mathrm{~cm} / \mathrm{yr})$ comparable to that of Java (and a $22{ }^{\circ} \mathrm{C}$ mean annual temperature) has $\mathrm{CO}_{2}$ consumption of only $\sim 55 \mathrm{t} \mathrm{CO}_{2} / \mathrm{yr} / \mathrm{km}^{2}$ (Dessert et al., 2001; White and Blum, 1995). Accordingly, we assign nominally $1 / 2$ of the weathering rate of basaltic terrain with a rough estimate of $25 \%$ uncertainty, or $50 \pm 12.5 \mathrm{t} \mathrm{CO}_{2} /$ $\mathrm{yr} / \mathrm{km}^{2}$, to mixed lithology (granitic-basaltic-gneissic) land areas under optimal weathering conditions.

The estimated parameters for the Greater Variscan orogen area straddling the equatorial humid belt are then used to calculate $\mathrm{CO}_{2}$ consumption fluxes for B (Late Carboniferous-Early Permian Pangea B) and A (Late Permian Pangea A): 

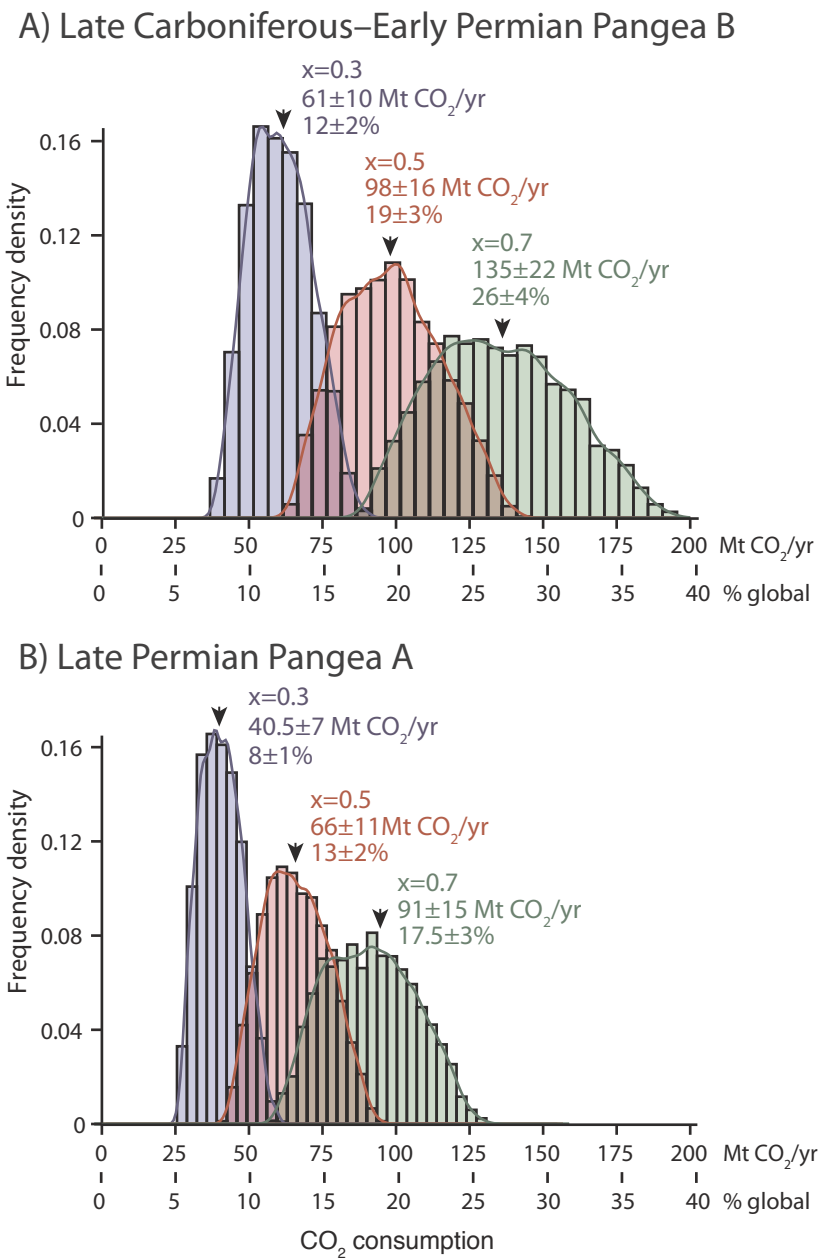

Fig. 10. Histogram frequency distributions and fitted kernel functions of 5000 randomized simulations of $\mathrm{CO}_{2}$ consumption rates for the Greater Variscan equatorial orogen in (A) Late Carboniferous-Early Permian Pangea B, and B) Late Permian Pangea A, assuming the fractional exposure area consisted of $0.3 \pm 0.05,0.5 \pm 0.05$, or $0.7 \pm 0.05$ mixed silicate lithologies (graniticbasaltic-gneissic) weathering at a nominal $\mathrm{CO}_{2}$ consumption rate of $50 \pm 12.5$ tonne $\mathrm{CO}_{2} / \mathrm{yr} / \mathrm{km}^{2}$ extrapolated from data in Dessert et al. (2003)

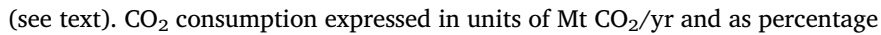
of global continental silicate weathering required to balance outgassing of 260 $\mathrm{Mt} \mathrm{CO}_{2} / \mathrm{yr}$

$\mathrm{B}(\mathrm{Mt} \mathrm{CO} / \mathrm{yr})=3.75 \pm 0.5 \mathrm{Mkm}^{2} * \mathrm{x} \pm 0.05 * 50 \pm 12.5 \mathrm{t} \mathrm{CO}_{2} / \mathrm{yr} / \mathrm{km}^{2}$

$\mathrm{A}(\mathrm{Mt} \mathrm{CO} / \mathrm{yr})=2.5 \pm 0.33 \mathrm{Mkm}^{2} * \mathrm{x} \pm 0.05 * 50 \pm 12.5 \mathrm{t} \mathrm{CO}_{2} / \mathrm{yr} / \mathrm{km}^{2}$

where $\mathrm{x}$ represents the crystalline fraction of the orogen expressed as $0.3(30 \%), 0.5(50 \%)$, and $0.7(70 \%)$ each with an assigned uncertainty $(1 \sigma)$ of 0.05 . We evaluate these equations statistically by generating 5000 random combinations of the three parameters within their uncertainty bounds. For B (Late Carboniferous-Early Permian Pangea B), we obtain rounded mean estimates of $61 \pm 10(1 \sigma) \mathrm{Mt} \mathrm{CO}_{2} / \mathrm{yr}$ consumption for $\mathrm{x}=0.3,98 \pm 16 \mathrm{Mt} \mathrm{CO}_{2} / \mathrm{yr}$ for $\mathrm{x}=0.5$, and $135 \pm 22$ $\mathrm{Mt} \mathrm{CO}_{2} / \mathrm{yr}$ for $\mathrm{x}=0.7$ (Fig. 10A); for A (Late Permian Pangea A), we obtain $40.5 \pm 7(1 \sigma) \mathrm{Mt} \mathrm{CO}_{2} / \mathrm{yr}$ for $\mathrm{x}=0.3,66 \pm 11 \mathrm{Mt} \mathrm{CO}_{2} / \mathrm{yr}$ for $\mathrm{x}=0.5$, and $91 \pm 15 \mathrm{Mt} \mathrm{CO}_{2} / \mathrm{yr}$ for $\mathrm{x}=0.7$ (Fig. 10B). We can express these $\mathrm{CO}_{2}$ consumption fluxes for the Greater Variscan orogen as percentages of global silicate weathering $\mathrm{CO}_{2}$ consumption required to balance the assumed outgassing flux of $260 \mathrm{Mt} \mathrm{CO}_{2} / \mathrm{yr}$; the percentages are $12 \pm 2 \%, 19 \pm 3 \%$, and $26 \pm 4 \%$ for Late Carboniferous-Early Permian Pangea B (Fig. 10A), and $8 \pm 1 \%, 13 \pm 2 \%$, and $17.5 \pm 3 \%$ for Late Permian Pangea A (Fig. 10B), in each case for $\mathrm{x}=0.3, \mathrm{x}=0.5$, and $\mathrm{x}=0.7$, respectively.

Considering the central option with $\mathrm{x}=0.5$, tectonically sliding only about $1.25 \mathrm{Mkm}^{2}$ of the Greater Variscan orogen hosting about $50 \%$ mixed silicate crystalline rocks out of the potent equatorial humid weathering belt would imply a reduction of 6 percentage points of global silicate weathering $\mathrm{CO}_{2}$ consumption from $19 \pm 3 \%$ in the Late Carboniferous-Early Permian to $13 \pm 2 \%$ in the Late Permian. If we attempt to incorporate also the effects of orogen beveling and siliciclastic-saprolith cover development (transport-limitation), then we could consider the option with $\mathrm{x}=0.5$ for the Late Carboniferous-Early Permian and the option with $\mathrm{x}=0.3$ for the Late Permian. This would imply that a reduction of 11 percentage points (19 $\pm 3 \%$ to $8 \pm 1 \%$ ) of global silicate weathering $\mathrm{CO}_{2}$ consumption. To place these estimates in perspective, we note that the $\mathrm{CO}_{2}$ consumption rates estimated by Dessert et al. (2003) correspond to nearly $9 \%$ for just the modern SE Asia volcanic arc province, and to about $1 / 3$ for all modern basaltic provinces, of total continental silicate weathering $\mathrm{CO}_{2}$ consumption.

In fact, the arc-continent collision complex of SE Asia/Indonesia that straddles the equator and has extraordinarily high $\mathrm{CO}_{2}$ consumption (Dessert et al., 2003) is the modern analogue of the Greater Variscan Orogen and is thought to be a major factor in maintaining low $p \mathrm{CO}_{2}$ for the ongoing Late Cenozoic Ice Age (Kent and Muttoni, 2013; Macdonald et al., 2019). Interestingly, SE Asia/Indonesia also has by far the greatest extent of tropical peatlands today (Page et al., 2011) even though the global ocean $\delta^{13} \mathrm{C}_{\text {carb }}$ record does not point to increasing organic carbon burial in the latter part of the Neogene (Derry and France-Lanord, 1996; Katz et al., 2005).

\section{Demise of the LPIA with a final hiccup}

Following the $\mathrm{CO}_{2}$ paradigm, we suppose that the demise of the LPIA resulted primarily from increasingly transport-limited carbon sequestration from silicate weathering as the Greater Variscan Orogen was flattened and accommodation space of the coal basins became reduced as these prime venues of carbon consumption drifted northward into the arid belt and continental area in the equatorial humid belt became reduced with transformation from Pangea B to Pangea A by the Late Permian. Indeed, the decrease in land area from the Pangea B to Pangea A transformation scaled to the modeling results of Goddéris et al. (2017) leads us to suggest that if higher $p \mathrm{CO}_{2}$ from collapse of an equatorial mountain belt led to the terminal throes of the LPIA by the Early Permian, the even higher $p \mathrm{CO}_{2}$ from reduction of equatorial land area could have ensured its final demise by the Late Permian.

However, there was a notable attempt to reverse the Permian

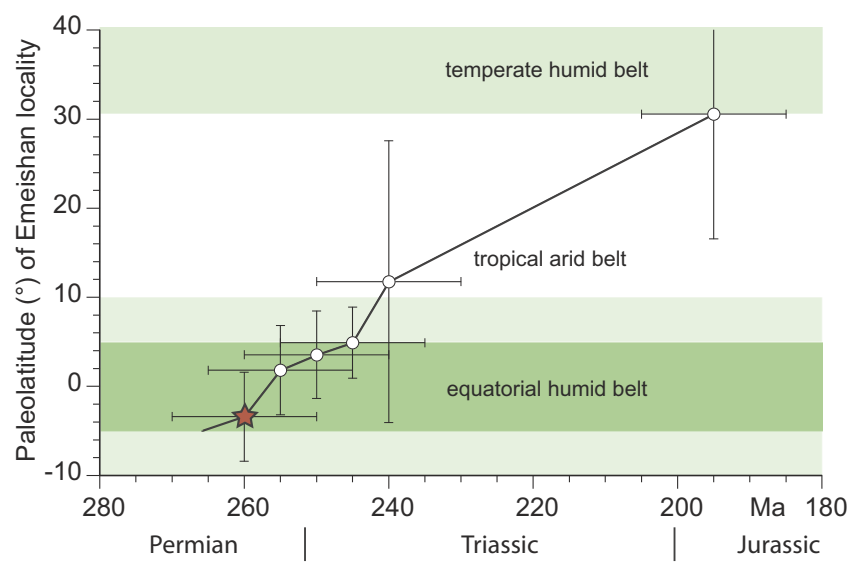

Fig. 11. Paleolatitudal progression of the $\sim 260$ Ma Emeishan large igneous province (star; present location at $27^{\circ} \mathrm{N} 102^{\circ} \mathrm{E}$; Xu et al., 2018) as a function of geologic time based on the apparent polar wander path for the South China Craton (Wu et al., 2017). 
warming at around $260 \mathrm{Ma}$ and through the Late Permian when $\delta^{18} \mathrm{O}$ values started to increase (cooler water temperatures) (Fig. 1G) and ${ }^{87} \mathrm{Sr} /{ }^{86} \mathrm{Sr}$ values also started to increase (more continental radiogenic sources) (Fig. 1E). The reversal in trends coincides with: 1) the emplacement of the Emeishan flood basalt province at $\sim 260 \mathrm{Ma}$ (Xu et al., 2018) virtually at the equator on the South China Block (Huang and Opdyke, 1998) and which remained within the equatorial humid belt for the rest of the Late Permian (Fig. 11); and 2) drift into the equatorial humid belt of the Cimmerian continental blocks that rifted off the northern margin of Gondwana in the Early Permian (Fig. 6). The preeruptive $\mathrm{CO}_{2}$ contents of flood basalts are estimated to be only around 0.2 to $0.5 \mathrm{wt} \%$ (e.g., Self et al., 2005) and even with a component of deep intrusive degassing (Black and Gibson, 2019), $\mathrm{CO}_{2}$ emissions that occur only on the order of a million years or less (Jicha et al., 2019) as for the canonical Deccan Traps (Schoene et al., 2019; Sprain et al., 2019) might have little prolonged climate warming effect (Caldeira and Rampino, 1990). On the other hand, flood basalts are $\mathrm{CaO}$ and $\mathrm{MgO}-$ rich ( 15 wt\% for the Emeishan; Shellnutt and Jahn, 2011) so that weathering of even a modest fraction of the Emeishan flood basalts ( $>0.5 \mathrm{Mkm}^{2}$; Courtillot and Renne, 2003), as we suggest occurred during their $\sim 10$ Myr passage through the equatorial humid belt in the Late Permian, could have resulted in an appreciable drawdown of $p \mathrm{CO}_{2}$. The increasing ${ }^{87} \mathrm{Sr} /{ }^{86} \mathrm{Sr}$ values in the Late Permian, on the other hand, are better attributed to more intense weathering of the Cimmerian continental blocks passing through the equatorial humid belt; their silicate weathering would have further increased $\mathrm{CO}_{2}$ consumption and help explain the cooling trend in the Late Permian.

Late Permian cooling ended with emplacement of the Siberian Traps flood basalts at around the Permian-Triassic boundary (252 Ma; Burgess et al., 2017). This was also about when the Emeishan flood basalt province drifted out of the equatorial humid weathering belt. Direct or indirect $\mathrm{CO}_{2}$ venting associated with the Siberian flood basalts may have been substantial given their vast size (Courtillot and Renne, 2003) and emplacement into organic-rich sediments (Svensen et al., 2009), and hence responsible for extreme albeit transient greenhouse conditions (Sun et al., 2012). Kump (2018) made the interesting suggestion that the $\mathrm{CO}_{2}$ emissions overwhelmed silicate weathering feedback regulation that was constrained by aridity associated with high continentality of Pangea and subdued global rock uplift. However, Pangea existed well before the Permian-Triassic boundary time and in fact, during the LPIA, whereas determining even regional uplift rates is strongly model-depend (e.g., Goddéris et al., 2017). Another explanation follows naturally from a combination of these discussed factors: 1) very low silicate weathering $\mathrm{CO}_{2}$ consumption compensating for emissions of the Siberian flood basalts due to their cold polar latitudes of emplacement that inhibit silicate weathering (Fig. 7C); 2) northward drift of the highly weatherable Emeishan flood basalts out of the equatorial humid belt (Fig. 11); and 3) drift of the already flattened Greater Variscan Orogen into the Zechstein arid belt that already reduced this once powerful sink of $\mathrm{CO}_{2}$ consumption by the Late Permian (Fig. 6A).

\section{Conclusions}

- Within the $\mathrm{CO}_{2}$ paradigm of climate change, we make the case that the Late Paleozoic Ice Age (LPIA) resulted from silicate weathering $\mathrm{CO}_{2}$ consumption driven by the Greater Variscan (AlleghenianMauritanide-Hercynian) collision zone between the southern margin of Laurasia and the northern margin of Gondwana forming Pangea B that was of wide meridional extent as it drifted northward into the equatorial humid belt by the Late Carboniferous where exhumed massifs experienced intense silicate weathering and shed sediment into nearby coal basins providing organic carbon burial. Horst exhumation and graben subsidence largely started to wane in the Early Permian and culminated with the tectonic transformation to Pangea A along a dextral shear zone that reduced continental area in the equatorial humid belt as the eroded orogen drifted into the tropical arid belt by the Late Permian. This tectonic scenario is strongly supported by the best available, least-biased paleomagnetic data that provide practically the only independent means of determining ancient latitudes.

- The LPIA coincides with the most extensive coal forests in Earth history whose inception correlates to increased organic carbon burial based on the $\delta^{13} \mathrm{C}$ marine carbonate record and which are closely related geographically and temporally with and quite possibly fertilized by enhanced silicate weathering of the equatorial Greater Variscan Orogen as the driver for reduced $\mathrm{pCO}_{2}$.

- The northward motion of Pangea and its transformation from Pangea B to Pangea A acted conjointly to produce an overall $30 \%$ reduction of continental land area within what we suggest was a narrow equatorial humid belt from the Late Carboniferous-Early Permian to the Late Permian, including a proportionate ( $\sim$ onethird) reduction of areal extent of the Greater Variscan Orogen by which time the eroded terrane drifted farther northward into the Zechstein arid belt that further reduced $\mathrm{CO}_{2}$ consumption from silicate weathering.

- The Emeishan continental flood basalt province that was emplaced on the South China Craton in an equatorial setting at $\sim 260 \mathrm{Ma}$ seemed to have reinvigorated $\mathrm{CO}_{2}$ weathering drawdown and thereby initiated a cooling trend in the Late Permian until the province drifted into the tropical arid belt by the Early Triassic.

- In contrast, the emplacement at the end of the Permian of the massive Siberian Traps in polar latitudes largely mitigated their weathering and $\mathrm{CO}_{2}$ consumption. Indeed, the volcanic and contact metamorphic emissions may well have overwhelmed a silicate weathering machine weakened from drift of weatherable Emeishan flood basalts and flattened Greater Variscan Orogen out of the equatorial humid belt and helped inaugurate a greenhouse world that effectively lasted until the Late Cenozoic Ice Age.

Supplementary data to this article can be found online at https:// doi.org/10.1016/j.palaeo.2020.109753.

\section{Declaration of competing interest}

The authors declare that they have no known competing financial interests or personal relationships that could have appeared to influence the work reported in this paper.

\section{Acknowledgements}

We thank Jitao Chen for sending us data listings, Jim Wright and Terry Plank for informative discussions about carbon isotope geochemistry and the $\mathrm{CO}_{2}$ outgassing budget, and Timothy Horscroft of Elsevier for encouraging us to prepare this paper for the journal. We appreciate the expeditious handling of the manuscript by the journal Editor (Thomas Algeo) and the thoughtful and constructive comments by the three reviewers (Lee Kump and two anonymous) that gave us an opportunity to improve our contribution. DK thanks the Paleomagnetic Research Fund at Lamont-Doherty Earth Observatory and the Board of Governors Discretionary Fund at Rutgers University for their support and GM wishes to thank the University of Milan for support of this research. This is LDEO Contribution \#8409.

\section{References}

Algeo, T.J., Scheckler, S.E., 1998. Terrestrial-marine teleconnections in the Devonian:

links between the evolution of land plants, weathering processes, and marine anoxic events. Philos. Trans. R. Soc. Lond. B 353, 113-130.

Algeo, T.J., Berner, R.A., Maynard, J.B., Scheckler, S., 1995. Late Devonian oceanic anoxic events and biotic crises: "rooted" in the evolution of vascular land plants? GSA Today 5 (45), 64-66.

Angiolini, L., Gaetani, M., Muttoni, G., Stephenson, M.H., Zanchi, A., 2007. Tethyan 
oceanic currents and climate gradients 300 m.y. ago. Geology 35, 1071-1074. Anonymous, 2018. Permian Basin Wolfcamp Shale Play, Geology Review. U.S. Energy Information Administration, pp. 1-15.

Arenas, R., Díez Fernández, R., Rubio Pascual, F.J., Sánchez Martínez, S., Martín Parra, L.M., Matas, J., González del Tánago, J., Jiménez-Díaz, A., Fuenlabrada, J.M., Andonaegui, P., Garcia-Casco, A., 2016. The Galicia-Ossa-Morena Zone: proposal for a new zone of the Iberian Massif. Variscan implications. Tectonophysics 681, $135-143$.

Argand, E., 1924. La tectonique de l'Asie. Conference faite á Bruxelles, le 10 aout 1922. Congres geologique international (XIIIe Session). pp. 171-372.

Arthaud, F., Matte, P., 1977. Late Paleozoic strike-slip faulting in southern Europe and northern Africa: result of a right-lateral shear zone between the Appalachians and the Urals. Geol. Soc. Am. Bull. 88, 1305-1320.

Aubele, K., Bachtadse, V., Muttoni, G., Ronchi, A., Durand, M., 2012. A paleomagnetic study of Permian and Triassic rocks from the Toulon-Cuers Basin, SE France: evidence for intra-Pangea block rotations in the Permian. Tectonics 31, TC3015. https://doi. org /10.1029/2011TC003026.

Aubele, K., Bachtadse, V., Muttoni, G., Ronchi, A., 2014. Paleomagnetic data from Late Paleozoic dykes of Sardinia: evidence for block rotations and implications for the intra-Pangea megashear system. Geochem. Geophys. Geosyst. 15 (5), 1684-1697.

Bachtadse, V., Aubele, K., Muttoni, G., Ronchi, A., Kirscher, U., Kent, D.V., 2018. New early Permian paleopoles from Sardinia confirm intra-Pangea mobility. Tectonophysics 749, 21-34.

Belica, M.E., Tohver, E., Pisarevsky, S.A., Jourdan, F., Denyszyn, S., George, A.D., 2017. Middle Permian paleomagnetism of the Sydney Basin, Eastern Gondwana: testing Pangea models and the timing of the end of the Kiaman Reverse Superchron. Tectonophysics 699, 178-198.

Bergman, N.M., Lenton, T.M., Watson, A.J., 2004. COPSE: a new model of biogeochemical cycling over Phanerozoic time. Am. J. Sci. 304, 397-437.

Berner, R.A., 1990. Atmospheric carbon dioxide levels over Phanerozoic time. Science 249, 1382-1386.

Berner, R.A., 1991. A model for atmospheric CO2 over Phanerozoic time. Am. J. Sci. 291, 339-376.

Berner, R.A., 1994. GEOCARB II: a revised model of atmospheric CO2 over Phanerozoic time. Am. J. Sci. 294, 56-91.

Berner, R.A., 2004. The Phanerozoic Carbon Cycle. Oxford University Press, Oxford (150 pp).

Berner, R.A., 2006. GEOCARBSULF: a combined model for Phanerozoic atmospheric O2 and CO2. Geochim. Cosmochim. Acta 70 (23), 5653-5664.

Berner, R.A., Kothalava, Z., 2001. GEOCARB III: a revised model of atmospheric CO2 over Phanerozoic time. Am. J. Sci. 301, 182-204.

Berner, R.A., Lasaga, A.C., Garrels, R.M., 1983. The carbonate-silicate geochemical cycle and its effect on atmospheric carbon dioxide over the past 100 million years. Am. J. Sci. 283, 641-683.

Bilardello, D., Kodama, K.P., 2010a. A new inclination shallowing correction of the Mauch Chunk Formation of Pennsylvania, based on high-field AIR results: implications for the Carboniferous North American APW path and Pangea reconstruction. Earth Planet. Sci. Lett. 299, 218-227.

Bilardello, D., Kodama, K.P., 2010b. Palaeomagnetism and magnetic anisotropy of Carboniferous red beds from the Maritime Provinces of Canada: evidence for shallow palaeomagnetic inclinations and implications for North American apparent polar wander. Geophys. J. Int. 180 (3), 1013-1029.

Bilardello, D., Callebert, W.C., Davis, J.R., 2018. Evidence for widespread remagnetizations in South America, case study of the Itarare Group rocks from the State of São Paulo, Brazil. Front. Earth Sci. 6 (182), 1-25. https://doi.org/10.3389/feart.2018. 00182.

Birgenheier, L.P., Frank, T.D., Fielding, C.R., Rygel, M.C., 2010. Coupled carbon isotopic and sedimentological records from the Permian system of eastern Australia reveal the response of atmospheric carbon dioxide to glacial growth and decay during the late Paleozoic Ice Age. Palaeogeogr. Palaeoclimatol. Palaeoecol. 286 (3-4), 178-193.

Black, B.A., Gibson, S.A., 2019. Deep carbon and the life cycle of large igneous provinces. Elements 15 (5), 319-324.

de Boer, J., 1965. Paleomagnetic indications of megatectonic movements in the Tethys. J. Geophys. Res. 70, 931-944.

Brandt, D., Ernesto, M., Rocha-Campos, A.C., dos Santos, P.R., 2009. Paleomagnetism of the Santa Fe Group, Central Brazil: implications for the late Paleozoic apparent polar wander path for South America. J. Geophys. Res. 114, B02101. https://doi.org/10. 1029/2008JB005735.

Bullard, E.C., Everett, J.E., Smith, A.G., 1965. A symposium on continental drift. IV. The fit of the continents around the Atlantic. Philos. Trans. R. Soc. Lond. A258, 41-51.

Burgess, S.D., Muirhead, J.D., Bowring, S.A., 2017. Initial pulse of Siberian Traps sills as the trigger of the end-Permian mass extinction. Nat. Commun. 8 (164), 1-6.

Caldeira, K., Rampino, M.R., 1990. Carbon dioxide emissions from Deccan volcanism and a K/T boundary greenhouse effect. Geophys. Res. Lett. 17 (1299-1232).

Cassinis, G., Perotti, C., 2007. A stratigraphic and tectonic review of the Italian Southern Alpine Permian. Palaeoworld 16 (1-3), 140-172.

Caves, J.K., Jost, A.B., Lau, K.V., Maher, K., 2016. Cenozoic carbon cycle imbalances and a variable weathering feedback. Earth Planet. Sci. Lett. 450, 152-163.

Channell, J.E.T., Horvath, F., 1976. The African/Adriatic promontory as a palaeogeographical premise for Alpine orogeny and plate movements in the Carpatho-Balkan region. Tectonophysics 35, 71-101.

Channell, J.E.T., D'Argenio, B., Horvath, F., 1979. Adria, the African promontory, in Mesozoic Mediterranean palaeogeography. Earth-Sci. Rev. 15, 213-292.

Chen, B., Joachimski, M.M., Shen, S.-Z., Lambert, L.L., Lai, X.-l., Wang, X.-d., Chen, J., Yuan, D.-x., 2013. Permian ice volume and palaeoclimate history: oxygen isotope proxies revisited. Gondwana Res. 24, 77-89.
Chen, J., Montañez, I.P., Qi, Y., Shen, S., Wang, X., 2018. Strontium and carbon isotopic evidence for decoupling of pCO2 from continental weathering at the apex of the late Paleozoic glaciation. Geology 46 (5), 395-398.

Clark, D.A., Lackie, M.A., 2003. Palaeomagnetism of the Early Permian Mount Leyshon Intrusive Complex and Tuckers Igneous Complex, North Queensland, Australia. Geophys. J. Int. 153, 523-547.

Cleal, C.J., Thomas, B.A., 2005. Palaeozoic tropical rainforests and their effect on global climates: is the past the key to the present? Geobiology 3, 13-31.

Cogné, J.P., 2003. PaleoMac: a Macintosh ${ }^{\mathrm{TM}}$ application for treating paleomagnetic data and making plate reconstructions. Geochem. Geophys. Geosyst. 4, 1007. https://doi. org/10.1029/2001GC000227.

Cogné, J.-P., Humler, E., 2004. Temporal variation of oceanic spreading and crustal production rates during the last 180 My. Earth Planet. Sci. Lett. 227, 427-439.

Correia, P., Murphy, J.B., 2020. Iberian-Appalachian connection is the missing link between Gondwana and Laurasia that confirms a Wegenerian Pangaea configuration. Sci. Rep. 10 (1), 2498.

Corsini, M., Rolland, Y., 2009. Late evolution of the southern European Variscan belt: Exhumation of the lower crust in a context of oblique convergence. C. R. Geoscience $341,214-223$.

Courtillot, V.E., Renne, P.R., 2003. On the ages of flood basalt events. Compt. Rendus Geosci. 335, 113-140.

Crowell, J.C., 1999. Pre-Mesozoic Ice Ages: Their Bearing on Understanding the Climate System. Geological Society of America Memoir 192. Geological Society of America, pp. 1-106.

Crowley, T.J., Baum, S.K., 1992. Modeling late Paleozoic glaciation. Geology 20 (6), 507-510.

Crowley, T.J., Berner, R.A., 2001. CO2 and climate change. Science 292 (5518), 870-872.

Crowley, T.J., Baum, S.K., Hyde, W.T., 1991. Climate model comparison of Gondwanan and Laurentide glaciations. J. Geophys. Res. Atmos. 96 (D5), 9217-9226.

Davies, C., Allen, M.B., Buslov, M.M., Safonova, I., 2010. Deposition in the Kuznetsk Basin, Siberia: insights into the Permian-Triassic transition and the Mesozoic evolution of Central Asia. Palaeogeogr. Palaeoclimatol. Palaeoecol. 295, 307-322.

Derder, M.E.-M., Henry, B., Merabet, N.-E., Daly, L., 1994. Palaeomagnetism of the Stephano-Autunian Lower Tiguentourine formations fromn stable Saharan craton (Algeria). Geopysical Journal International 116, 12-22.

Derder, M.E.M., Henry, B., Maouche, S., Merabet, N.E., Amenna, M., Bayou, B., 2019. Paleomagnetism of the Western Saharan basins: an overview. In: Bendaoud, A. (Ed.), The Geology of the Arab World-An Overview. Springer Nature Switzerland, pp. 291-318.

Derry, L.A., France-Lanord, C., 1996. Neogene growth of the sedimentary organic carbon reservoir. Paleoceanography 11 (3), 267-275.

Dessert, C., Dupré, B., Francois, L.M., Schott, J.J., Gaillardet, J., Chakrapani, G., Bajpai, S., 2001. Erosion of Deccan Traps determined by river geochemistry: impact on the global climate and the ${ }^{87} \mathrm{Sr} /{ }^{86} \mathrm{Sr}$ ratio of seawater. Earth Planet. Sci. Lett. 188, 459-474.

Dessert, C., Dupré, B., Gaillardet, J., Francois, L., Allègre, C., 2003. Basalt weathering laws and the impact of basalt weathering on the global carbon cycle. Chem. Geol. 202, 257-273.

Diez Fernández, R., Catalán, J.R.M., Gerdes, A., Abati, J., Arenas, R., Fernández-Suárez, J., 2010. U-Pb ages of detrital zircons from the basal allochthonous units of NW Iberia: Provenance and paleoposition on the northern margin of Gondwana during the Neoproterozoic and Paleozoic. Gondwana Res. 18 (2-3), 385-399.

Domeier, M., Van der Voo, R., Torsvik, T.H., 2012. Paleomagnetism and Pangea: the road to reconciliation. Tectonophysics 514-517-43.

Donnadieu, Y., Pierrehumbert, R., Jacob, R., Fluteau, F., 2006. Modelling the primary control of paleogeography on Cretaceous climate. Earth Planet. Sci. Lett. 248 (1-2), 426-437.

Du Toit, A.L., 1937. Our Wandering Continents: An Hypothesis of Continental Drifting. Oliver and Boyd, Edinburgh, pp. 1-366.

Edmond, J.M., 1992. Himalayan tectonics, weathering processes, and the strontium isotope record in marine limestones. Science 258, 1594-1597.

Elmore, R.D., Muxworthy, A.R., Aldana, M.M., Mena, M., 2012. Remagnetization and Chemical Alteration of Sedimentary Rocks. 371 Geological Society, London Special Publication. (282 pp).

Elter, F., Gaggero, L., Mantovani, F., Pandeli, E., Costamagna, L.G., 2020. The Atlas-East Variscan -Elbe shear system and its role in the formation of the pull-apart Late Palaeozoic basins. Int. J. Earth Sci. 109, 739-760.

Feulner, G., 2017. Formation of most of our coal brought Earth close to global glaciation. Proc. Natl. Acad. Sci. 114 (43), 11333-11337.

Fielding, C.R., Frank, T.D., Birgenheier, L.P., Rygel, M.C., Jones, A.T., Roberts, J., 2008a. Stratigraphic imprint of the Late Palaeozoic Ice Age in eastern Australia: a record of alternating glacial and nonglacial climate regime. J. Geol. Soc. 165, 129-140.

Fielding, C.R., Frank, T.D., Isbell, J.L., 2008b. The late Paleozoic ice age-a review of current understanding and synthesis of global climate patterns. Geol. Soc. Am. Spec. Pap. 441, 343-354.

Fluteau, F., Besse, J., Broutin, J., Ramstein, G., 2001. The Late Permian climate. What can be inferred from climate modelling concerning Pangea scenarios and Hercynian range altitude? Palaeogeogr. Palaeoclimatol. Palaeoecol. 167, 39-71.

Font, E., Rapalini, A.E., Tomezzoli, R.N., Trindade, R.I.F., Tohver, E., 2012. Episodic remagnetizations related to tectonic events and their consequences for the South America Polar Wander Path. Geol. Soc. Lond., Spec. Publ. 371 (1), 55.

Francois, L.M., Walker, J.C.G., 1992. Modelling the Phanerozoic carbon cycle and climate: constraints from the ${ }^{87} \mathrm{Sr} /{ }^{86} \mathrm{Sr}$ isotopic ratio of seawater. Am. J. Sci. 292, 81-135.

Franke, W., 2014. Topography of the Variscan orogen in Europe: failed-not collapsed. Int. J. Earth Sci. 103 (5), 1471-1499. 
Franke, W., Cocks, L.R.M., Torsvik, T.H., 2019. Detrital zircons and the interpretation of palaeogeography, with the Variscan Orogeny as an example. Geol. Mag. 1-5.

Gaffin, S., 1987. Ridge volume dependence on seafloor generation rate and inversion using long term sealevel change. Am. J. Sci. 287, 596-611.

Gaillardet, J., Dupré, B., Louvat, P., Allègre, C.J., 1999. Global silicate weathering and CO2 consumption rates deduced from the chemistry of large rivers. Chem. Geol. 159, $3-30$.

Gallo, L.C., Tomezzoli, R.N., godd, E.O., 2017. A pure dipole analysis of the Gondwana apparent polar wander path: paleogeographic implications in the evolution of Pangea. Geochem. Geophys. Geosyst. 18 (4), 1499-1519.

Garde, A.A., Boriani, A., Sørensen, E.V., 2015. Crustal modelling of the Ivrea-Verbano zone in northern Italy re-examined: coseismic cataclasis versus extensional shear zones and sideways rotation. Tectonophysics $662,291-311$.

Gerlach, T., 2011. Volcanic versus anthropogenic carbon dioxide. EOS Trans. Am. Geophys. Union 92, 201-202.

Geuna, S.E., Escosteguy, L.D., 2004. Palaeomagnetism of the Upper Carboniferous-Lower Permian transition from Paganzo basin, Argentina. Geophys. J. Int. 157, 1071-1089.

Glasspool, I.l., Scott, A.C., Waltham, D., Pronina, N., Shao, L., 2015. The impact of fire on the Late Paleozoic Earth system. Front. Plant Sci. 6 (756), 1-13.

Glennie, K.W., 1986. Development of N.W. Europe's southern Permian gas basin. Geol. Soc. Spec. Publ. 23, 3-22.

Goddéris, Y., Donnadieu, Y., 2019. A sink- or a source-driven carbon cycle at the geological timescale? Relative importance of palaeogeography versus solid Earth degassing rate in the Phanerozoic climatic evolution. Geol. Mag. 156 (2), 355-365.

Goddéris, Y., Donnadieu, Y., Carretier, S., Aretz, M., Dera, G., Macouin, M., Regard, V., 2017. Onset and ending of the late Palaeozoic ice age triggered by tectonically paced rock weathering. Nat. Geosci. 10 (5), 382-386.

Gold, T., 1955. Instability of the Earth's axis of rotation. Nature 175, 526-529.

Goldreich, P., Toomre, A., 1969. Some remarks on polar wandering. J. Geophys. Res. 74, 2555-2567.

Golonka, J., 2002. Plate-tectonic maps of the Phanerozoic. SEPM Spec. Publ. 72, 21-75.

Gradstein, F.M., Ogg, J.G., Schmitz, M.D., Ogg, G.M. (Eds.), 2012. The Geologic Time Scale 2012. Elsevier, Amsterdam (1144 pp).

Greb, S.F., DiMichele, W.A., Gastaldo, R.A., 2006. Evolution and importance of wetlands in earth history. Geol. Soc. Am. Spec. Pap. 399, 1-40. https://doi.org/10.1130/2006. 2399(01).

Griffis, N.P., Montañez, I.P., Mundil, R., Richey, J., Isbell, J., Fedorchuk, N., Linol, B., Iannuzzi, R., Vesely, F., Mottin, T., Rosa, E.d., Keller, B., Yin, Q.-Z., 2019. Coupled stratigraphic and U-Pb zircon age constraints on the late Paleozoic icehouse-togreenhouse turnover in south-central Gondwana. Geology 47 (12), 1146-1150. https://doi.org/10.1130/G46740.1.

Hammer, Ø., Harper, D.A.T., Ryan, P.D., 2001. PAST: paleontological statistics software package for education and data analysis. Palaeontol. Electron. 4 (1) 9pp. http:// palaeo-electronica.org/2001_1/past/issue1_01.htm.

Hayes, J.M., Strauss, H., Kaufman, A.J., 1999. The abundance of 13C in marine organic matter and isotopic fractionation in the global biogeochemical cycle of carbon during the past $800 \mathrm{Ma}$. Chem. Geol. 161, 103-125.

Heeremans, M., Timmerman, M., Kirstein, L.A., Faleide, J.I., 2004. New constraints on the timing of late Carboniferous-early Permian volcanism in the central North Sea. Geol. Soc. Lond., Spec. Publ. 223, 177-194.

Horton, D.E., Poulsen, C.J., Pollard, D., 2010. Influence of high-latitude vegetation feedbacks on late Palaeozoic glacial cycles. Nat. Geosci. 3, 572.

Huang, K., Opdyke, N.D., 1991. Paleomagnetic results from the upper Carboniferous of the Shan-Thai-Malay block of western Yunnan, China. Tectonics 192, 333-344.

Huang, K., Opdyke, N.D., 1998. Magnetostratigraphic investigations on an Emeishan basalt section in western Guizhou province, China. Earth Planet. Sci. Lett. 163, 1-14.

Huang, K., Opdyke, N.D., Peng, X., Li, J., 1992. Paleomagnetic results from the Upper Permian of the eastern Qiangtang Terrane of Tibet and their tectonic implications. Earth Planet. Sci. Lett. 111, 1-10.

Irving, E., 1977. Drift of the major continental blocks since the Devonian. Nature 270, 304-309.

Irving, E., 2004. The case for Pangea B, and the intra-Pangean megashear. In: Channell, J.E.T., Kent, D.V., Lowrie, W., Meert, J.G. (Eds.), Timescales of the Paleomagnetic Field, Geophysical Monograph. 145. American Geophysical Union, Washington, D.C, pp. 13-27.

Isbell, J.L., Henry, L.C., Gulbranson, E.L., Limarino, C.O., Fraiser, M.L., Koch, Z.J., Ciccioli, P.L., Dineen, A.A., 2012. Glacial paradoxes during the late Paleozoic ice age: evaluating the equilibrium line altitude as a control on glaciation. Gondwana Res. 22 (1), 1-19.

Jagoutz, O., Macdonald, F.A., Royden, L., 2016. Low-latitude arc-continent collision as a driver for global cooling. Proc. Natl. Acad. Sci. 113 (18), 4935-4940.

Jicha, B.R., Singer, B.S., Li, Y., 2019. Intercalibration of 40Ar/39Ar laboratories in China, the USA and Russia for Emeishan volcanism and the Guadalupian-Lopingian boundary. National Science Review 6 (4), 614-616. https://doi.org/10.1093/nsr/ nwz044.

Katz, M.E., Wright, J.D., Miller, K.G., Cramer, B.S., Fennel, K., Falkowski, P.G., 2005. Biological overprint of the geological carbon cycle. Mar. Geol. 217, 323-338.

Kent, D.V., Irving, E., 2010. Influence of inclination error in sedimentary rocks on the Triassic and Jurassic apparent polar wander path for North America and implications for Cordilleran tectonics. J. Geophys. Res. 115, B10103. https://doi.org/10.1029/ 2009JB007205.

Kent, D.V., Muttoni, G., 2008. Equatorial convergence of India and early Cenozoic climate trends. Proc. Natl. Acad. Sci. 105, 16065-16070.

Kent, D.V., Muttoni, G., 2013. Modulation of Late Cretaceous and Cenozoic climate by variable drawdown of atmospheric pCO2 from weathering of basaltic provinces on continents drifting through the equatorial humid belt. Clim. Past 9, 525-546.
Korte, M., Ullmann, C.V., 2018. Permian strontium isotope stratigraphy. Geological Society, London 450 (1), 105-118. https://doi.org/10.1144/SP450.5. Special Publications.

Kumar, P., Yuan, X., Kumar, M.R., Kind, R., Li, X., Chadha, R.K., 2007. The rapid drift of the Indian tectonic plate. Nature 449 (7164), 894-897.

Kump, L.R., 2018. Prolonged Late Permian-Early Triassic hyperthermal: failure of climate regulation? Phil. Trans. R. Soc. A 376, 2130.

Kump, L.R., Arthur, M.A., 1997. Global chemical erosion during the Cenozoic: weatherability balances the budgets. In: Ruddiman, W.F. (Ed.), Tectonic Uplift and Climate Change. Plenum Press, New York, pp. 399-426.

Kump, L.R., Arthur, M.A., 1999. Interpreting carbon-isotope excursions: carbonates and organic matter. Chem. Geol. 161 (1-3), 181-198.

Kutzbach, J.E., Gallimore, R.G., 1989. Pangaean climates: megamonsoons of the megacontinent. J. Geophys. Res. 94 (D3), 3341-3357.

Lanci, L., Tohver, E., Wilson, A., Flint, S., 2013. Upper Permian magnetic stratigraphy of the lower Beaufort Group, Karoo Basin. Earth Planet. Sci. Lett. 375, 123-134.

Li, G., Elderfield, H., 2013. Evolution of carbon cycle over the past 100 million years. Geochim. Cosmochim. Acta 103, 11-25.

Linnemann, U., McNaughton, N.J., Romer, R.L., Gehmlich, M., Drost, K., Tonk, C., 2004. West African provenance for Saxo-Thuringia (Bohemian Massif): did Armorica ever leave pre-Pangean Gondwana? - U/Pb-SHRIMP zircon evidence and the Nd-isotopic record. Int. J. Earth Sci. 93, 683-705.

Liu, G., 1990. Permo-Carboniferous paleogeography and coal accumulation and their tectonic control in the North and South China continental plates. Int. J. Coal Geol. 16, 73-117.

Lottes, A.L., Rowley, D.B., 1990. Reconstruction of the Laurasian and Gondwanan segments of Permian Pangaea. In: McKerrow, W.S., Scotese, C.R. (Eds.), Palaeozoic Palaeogeography and Biogeography, Memoir 12. Geological Society, London, pp. 383-395.

Lowry, D.P., Poulsen, C.J., Horton, D.E., Torsvik, T.H., Pollard, D., 2014. Thresholds for Paleozoic ice sheet initiation. Geology 42 (7), 627-630.

Macdonald, F.A., Swanson-Hysell, N.L., Park, Y., Lisiecki, L., Jagoutz, O., 2019. Arc continent collisions in the tropics set Earth's climate state. Science 364 (6436), 181.

Machlus, M.L., Shea, E.K., Hemming, S., Ramezani, J., Rasbury, E.T., 2020. An assessment of sanidine from the Fire Clay tonstein as a Carboniferous 40Ar/39Ar monitor standard and for inter-method comparison to U-Pb zircon geochronology. Chem. Geol. 539, 119485. https://doi.org/10.1016/j.chemgeo.2020.119485.

Magaritz, M., Holser, W.t., 1990. Carbon isotope shifts in Pennsylvanian seas. Am. J. Sci. 290, 977-994.

Manabe, S., Bryan, K., 1985. CO2-induced change in a coupled ocean-atmosphere model and its paleoclimatic implications. J. Geophys. Res. 90 (C6), 11689-11707.

Martens, U., Weber, B., Valencia, V.A., 2009. U/Pb geochronology of Devonian and older Paleozoic beds in the southeastern Maya block, Central America: its affinity with periGondwanan terranes. Geol. Soc. Am. Bull. 122 (5/6), 815-829.

Marty, B., Tolstikhin, I.N., 1998. CO2 fluxes from mid-ocean ridges, arcs and plumes. Chem. Geol. 145, 233-248.

Metcalfe, I., Crowley, J.L., Nicoll, R.S., Schmitz, M., 2015. High-precision U-Pb CA-TIMS calibration of Middle Permian to Lower Triassic sequences, mass extinction and extreme climate-change in eastern Australian Gondwana. Gondwana Res. 28 (1) $61-81$.

Michel, L.A., Tabor, N.J., Montañez, I.P., Schmitz, M.D., Davydov, V.I., 2015. Chronostratigraphy and paleoclimatology of the Lodève Basin, France: evidence for a pan-tropical aridification event across the Carboniferous-Permian boundary. Palaeogeogr. Palaeoclimatol. Palaeoecol. 430, 118-131.

Mitrovica, J.X., Wahr, J., 2011. Ice age Earth rotation. Annu. Rev. Earth Planet. Sci. 39, $577-616$.

Montañez, I.P., 2016. A Late Paleozoic climate window of opportunity. Proc. Natl. Acad. Sci. 113 (9), 2334-2336. https://doi.org/10.1073/pnas.1600236113.

Montañez, I.P., Poulsen, C.J., 2013. The Late Paleozoic Ice Age: an evolving paradigm. Annu. Rev. Earth Planet. Sci. 41, 24.1-24.28.

Montañez, I.P., Tabor, N.J., Niemeier, D., DiMichele, W.A., Frank, T.D., Fielding, C.R. Isbell, J.L., Birgenheier, L.P., Rygel, M.C., 2007. CO2-forced climate and vegetation instability during Late Paleozoic deglaciation. Science 315, 87-91.

Montañez, I.P., McElwain, J.C., Poulsen, C.J., White, J.D., DiMichele, William A., Wilson, J.P., Griggs, G., Hren, M.T., 2016. Climate, pCO2 and terrestrial carbon cycle linkages during late Palaeozoic glacial-interglacial cycles. Nat. Geosci. 9, 824.

Morel, P., Irving, E., 1981. Paleomagnetism and the evolution of Pangea. J. Geophys. Res. 86, 1858-1987.

Murphy, J., Gutierrez-Alonso, G., 2008. The origin of the Variscan upper allochthons in the Ortegal Complex, northwestern Iberia: Sm-Nd isotopic constraints on the closure of the Rheic Ocean. Can. J. Earth Sci. 45, 651-668.

Murphy, J.B., Cousens, B.L., Braid, J.A., Strachan, R.A., Dostal, J., Keppie, J.D., Nance, R.D., 2011. Highly depleted oceanic lithosphere in the Rheic Ocean: implications for Paleozoic plate reconstructions. Lithos 123 (1), 165-175.

Muttoni, G., Kent, D.V., 2019a. Adria as promontory of Africa and its conceptual role in the Tethys Twist and Pangea B to Pangea A transformation in the Permian. Riv. Ital. Paleontol. Stratigr. 125 (1), 249-269.

Muttoni, G., Kent, D.V., 2019b. Jurassic monster polar shift confirmed by sequential paleopoles from Adria, promontory of Africa. J. Geophys. Res. 124. https://doi.org/ 10.1029/2018JB017199.

Muttoni, G., Kent, D.V., Channell, J.E.T., 1996. Evolution of Pangea: paleomagnetic constraints from the Southern Alps, Italy. Earth Planet. Sci. Lett. 140, 97-112.

Muttoni, G., Kent, D.V., Garzanti, E., Brack, P., Abrahamsen, N., Gaetani, M., 2003. Early Permian Pangea 'B' to Late Permian Pangea 'A' Earth Planet. Sci. Lett. 215, 379-394.

Muttoni, G., Gaetani, M., Kent, D.V., Sciunnach, D., Angiolini, L., Berra, F., Garzanti, E., Mattei, M., Zanchi, A., 2009a. Opening of the Neo-Tethys Ocean and the Pangea B to 
Pangea A transformation during the Permian. GeoArabia 14, 17-48.

Muttoni, G., Mattei, M., Balini, M., Zanchi, A., Gaetani, M., Berra, F., 2009b. The drift history of Iran from the Ordovician to the Triassic. Geol. Soc. Lond., Spec. Publ. 312, $7-29$.

Nelsen, M.P., DiMichele, W.A., Peters, S.E., Boyce, C.K., 2016. Delayed fungal evolution did not cause the Paleozoic peak in coal production. Proc. Natl. Acad. Sci. 113 (9), 2442-2447.

Opdyke, N.D., Roberts, J., Claoue-Long, J., Irving, E., Jones, P.J., 2000. Base of the Kiaman: its definition and global stratigraphic significance. Geol. Soc. Am. Bull. 112, $1315-1341$.

Page, S.E., Rieley, J.O., Banks, C.J., 2011. Global and regional importance of the tropical peatland carbon pool. Glob. Chang. Biol. 17 (2), 798-818.

Pastor-Galán, D., Gutiérrez-Alonso, G., Murphy, J.B., Fernández-Suárez, J., Hofmann, M., Linnemann, U., 2013. Provenance analysis of the Paleozoic sequences of the northern Gondwana margin in NW Iberia: passive margin to Variscan collision and orocline development. Gondwana Res. 23 (3), 1089-1103.

Pastor-Galán, D., Pueyo, E.L., Diederen, M., García-Lasanta, C., Langereis, C.G., 2018. Late Paleozoic Iberian orocline(s) and the missing shortening in the core of Pangea. Paleomagnetism from the Iberian range. Tectonics 37 (10), 3877-3892.

Pfeifer, L.S., Soreghan, G.S., Pochat, S.p., Driessche, J.V.D., Thomson, S.N., 2018. Permian exhumation of the Montagne Noire core complex recorded in the Graissessac-Lodeve Basin, France. Basin Res. 30 (Suppl. 1), 1-14.

Pochat, S., Driessche, J.V.D., 2011. Filling sequence in Late Paleozoic continental basins: a chimera of climate change? A new light shed given by the Graissessac-Lodève basin (SE France). Palaeogeogr. Palaeoclimatol. Palaeoecol. 302, 170-186.

Rakotosolofo, N.A., Tait, J.A., Carlotto, V., Cárdenas, J., 2006. Palaeomagnetic results from the Early Permian Copacabana Group, southern Peru: implication for Pangaea palaeogeography. Tectonophysics 413 (3-4), 287-299.

Rees, P.M., Ziegler, A.M., Gibbs, M.T., Kutzbach, J.E., Behling, P.J., Rowley, D.B., 2002. Permian phytogeographic patterns and climate data/model comparisons. The Journal of Geology 110, 1-31.

Reichow, M.K., Pringle, M.S., Al'Mukhamedov, A.I., Allen, M.B., Andreichev, V.L., Buslov, M.M., Davies, C.E., Fedoseev, G.S., Fitton, J.G., Inger, S., Medvedev, A.Y., Mitchell, C., Puchkov, V.N., Safonova, I.Y., Scott, R.A., Saunders, A.D., 2009. The timing and extent of the eruption of the Siberian Traps large igneous province: implications for the end-Permian environmental crisis. Earth Planet. Sci. Lett. 277, 9-20.

Rowley, D.B., 2002. Rate of plate creation and destruction: 180 Ma to present. Geol. Soc. Am. Bull. 114, 927-933.

Royer, D.L., 2014. Atmospheric CO2 and O2 during the Phanerozoic: tools, patterns, and impacts. In: Holland, H., Turekian, K.K. (Eds.), Treatise on Geochemistry. Elsevier, Amsterdam, pp. 251-267.

Sachsenhofer, R.F., Privalov, V.A., Panova, E.A., 2012. Basin evolution and coal geology of the Donets Basin (Ukraine, Russia): an overview. Int. J. Coal Geol. 89, 26-40.

Schaltegger, U., Brack, P., 2007. Crustal-scale magmatic systems during intracontinental strike-slip tectonics: $\mathrm{U}, \mathrm{Pb}$ and $\mathrm{Hf}$ isotopic constraints from Permian magmatic rocks of the Southern Alps. Int. J. Earth Sci. 96, 1131-1151.

Schaltegger, U., Corfu, F., 1995. Late Variscan "Basin and Range" magmatism and tectonics in the Central Alps: evidence from U-Pb geochronology. Geodinamica Acta (Paris) 8, 82-98.

Schoene, B., Eddy, M.P., Samperton, K.M., Keller, C.B., Keller, G., Adatte, T., Khadri, S.F.R., 2019. U-Pb constraints on pulsed eruption of the Deccan Traps across the endCretaceous mass extinction. Science 363 (6429), 862.

Schrag, D.P., Berner, R.A., Hoffman, P.F., Halverson, G.P., 2002. On the initiation of a snowball Earth. Geochem. Geophys. Geosyst. 3 (6). https://doi.org/10.1029/ 2001GC000219.

Sciunnach, D., 2001. Benthic foraminifera from the upper Collio Formation (Lower Permian, Lombardy Southern Alps): implications for the palaeogeography of the periTethyan area. Terra Nova 13, 150-155.

Scotese, C.R., Langford, R.P., 1995. Pangea and the paleogeography of the Permian. In: Scholle, P.A., Peryt, T.M., Ulmer-Scholle, D.S. (Eds.), The Permian of Northern Pangea. Paleogeography, Paleoclimates, Stratigraphy. Springer, Berlin, pp. 3-19.

Self, S., Thordarson, T., Widdowson, M., 2005. Gas fluxes from flood basalt eruptions. Elements 1, 283-287.

Şengör, A.M.C., Natal'in, B.A., Sunal, G., van der Voo, R., 2013. The tectonics of the Altaids: crustal growth during the construction of the continental lithosphere of Central Asia between $\sim 750$ and $\sim 130$ Ma ago. Annu. Rev. Earth Planet. Sci. 46 (1), 838-849.

Shao, L., Wang, H., Yu, X., Zhang, M., 2012. Paleo-fires and atmospheric oxygen levels in the latest Permian: evidence from maceral compositions of coals in Eastern Yunnan, Southern China. Acta Geol. Sin. (English Edition) 86, 949-962.

Shellnutt, J.G., Jahn, B.M., 2011. Origin of Late Permian Emeishan basaltic rocks from the Panxi region (SW China): implications for the Ti-classification and spatial-compositional distribution of the Emeishan flood basalts. J. Volcanol. Geotherm. Res. 199 (1), 85-95.

Sprain, C.J., Renne, P.R., Vanderkluysen, L., Pande, K., Self, S., Mittal, T., 2019. The eruptive tempo of Deccan volcanism in relation to the Cretaceous-Paleogene boundary. Science 363 (6429), 866.

Stallard, R.F., Edmond, J.M., 1983. Geochemistry of the Amazon. 2. The influence of geology and weathering environment on the dissolved-load. J. Geophys. Res. 88 (C14), 9671-9688.

Stephan, T., Kroner, U., Romer, R.L., Rösel, D., 2019. From a bipartite Gondwanan shelf to an arcuate Variscan belt: the early Paleozoic evolution of northern Peri-Gondwana. Earth Sci. Rev. 192, 491-512.

Stephenson, R.A., Narkiewicz, M., Dadlez, R., van Wees, J.-D., Andriessen, P., 2003. Tectonic subsidence modelling of the Polish Basin in the light of new data on crustal structure and magnitude of inversion. Sediment. Geol. 156 (1-4), 59-70.

Sun, Y., Joachimski, M.M., Wignall, P.B., Yan, C., Chen, Y., Jiang, H., Wang, L., Lai, X., 2012. Lethally Hot Temperatures During the Early Triassic Greenhouse. Science 338 (6105), 366-370.

Svensen, H., Planke, S., Polozov, A.G., Schmidbauer, N., Corfu, F., Podladchikov, Y.Y., Jamtveit, B., 2009. Siberian gas venting and the end-Permian environmental crisis Earth Planet. Sci. Lett. 277, 490-500.

Tabor, N.J., Poulsen, C.J., 2008. Palaeoclimate across the Late Pennsylvanian-Early Permian tropical palaeolatitudes: a review of climate indicators, their distribution, and relation to palaeophysiographic climate factors. Palaeogeogr. Palaeoclimatol. Palaeoecol. 268 (3), 293-310.

Tauxe, L., Kent, D.V., 2004. A simplified statistical model for the geomagnetic field and the detection of shallow bias in paleomagnetic inclinations: was the ancient magnetic field dipolar? In: Channell, J.E.T., Kent, D.V., Lowrie, W., Meert, J. (Eds.), Timescales of the Paleomagnetic Field, Geophysical Monograph. 145. American Geophysical Union, Washington, D.C, pp. 101-116.

Timmerman, M.J., 2004. Timing, geodynamic setting and character of PermoCarboniferous magmatism in the foreland of the Variscan Orogen, NW Europe. Geol. Soc. Lond., Spec. Publ. 223, 41-74.

Torsvik, T.H., Van der Voo, R., Preeden, U., Mac Niocaill, C., Steinberger, B., Doubrovine, P.V., van Hinsbergen, D.J.J., Domeier, M., Gaina, C., Tohver, E., Meert, J.G., McCausland, P.J.A., Cocks, L.R.M., 2012. Phanerozoic polar wander, palaeogeography and dynamics. Earth Sci. Rev. 114, 325-368.

Tsai, V.C., Stevenson, D.J., 2007. Theoretical constraints on true polar wander. J. Geophys. Res. 112, B05415. https://doi.org/10.1029/2005JB003923.

Vail, P.R., Mitchum Jr., R.M., Thompson, S., 1977. Seismic stratigraphy and global changes of sea level, part 4: global cycles of relative changes of sea level. AAPG Mem. 26, 83-97. https://doi.org/10.1306/M26490C6.

Van der Voo, R., French, R.B., 1974. Apparent polar wandering for the Atlantic-bordering continents: Late Carboniferous to Eocene. Earth Sci. Rev. 10, 99-119.

Van Hilten, D., 1964. Evaluation of some geotectonic hypotheses by paleomagnetism. Tectonophysics 1 (1), 3-5.

van Hinsbergen, D.J.J., Torsvik, T.H., Schmid, S.M., Maţenco, L.C., Maffione, M., Vissers, R.L.M., Gürer, D., Spakman, W., 2020. Orogenic architecture of the Mediterranean region and kinematic reconstruction of its tectonic evolution since the Triassic. Gondwana Res. 81, 79-229. https://doi.org/10.1016/j.gr.2019.07.009.

Veevers, J., Tweari, R.C., 1995. Permian-Carboniferous and Permian-Triassic magmatism in the rift zone bordering the Tethyan margin of southern Pangea. Geology 23 (5), $467-470$.

Veizer, J., Ala, D., Azmy, K., Bruckschen, P., Buhl, D., Bruhn, F., Carden, G.A.F., Diener, A., Ebneth, S., Godderis, Y., 1999. 87Sr/86Sr, [delta]13C and [delta]180 evolution of Phanerozoic seawater. Chem. Geol. 161 (1-3), 59-88.

Visonà, D., Fioretti, A.M., Poli, M.E., Zanferrari, A., Fanning, M., 2007. U-Pb SHRIMPzircon dating of andesite from the Dolomite area (NE Italy): geochronological evidence for the early onset of Permian volcanism in the eastern part of the southern Alps. Swiss J. Geosci. 100, 313-324.

Walker, J.C.G., Hays, P.B., Kasting, J.F., 1981. A negative feedback mechanism for the long-term stabilization of Earth's surface-temperature. J. Geophys. Res.-Atmos. 86, 9776-9782.

Wang, H., Shao, L., Hao, L., Zhang, P., Glasspool, I.J., Wheeley, J.R., Wignall, P.B., Yi, T., Zhang, M., Hilton, J., 2011. Sedimentology and sequence stratigraphy of the Lopingian (Late Permian) coal measures in southwestern China. Int. J. Coal Geol. 85 (1), 168-183.

Wang, J., Pfefferkorn, H.W., Zhang, Y., Feng, Z., 2012. Permian vegetational Pompeii from Inner Mongolia and its implications for landscape paleoecology and paleobiogeography of Cathaysia. Proc. Natl. Acad. Sci. 109 (13), 4927.

White, A.F., Blum, A.E., 1995. Effects of climate on chemical weathering in watersheds. Geochim. Cosmochim. Acta 59 (9), 1729-1747.

Wu, L., Kravchinsky, V.A., Potter, D.K., 2017. Apparent polar wander paths of the major Chinese blocks since the Late Paleozoic: toward restoring the amalgamation history of east Eurasia. Earth Sci. Rev. 171, 492-519.

Xu, Y., Yang, Z., Tong, Y.-B., Jing, X., 2018. Paleomagnetic secular variation constraints on the rapid eruption of the Emeishan continental flood basalts in southwestern China and northern Vietnam. J. Geophys. Res. Solid Earth 123, 2597-2617.

Yan, Y., Huang, B., Zhang, D., Charusiri, P., Veeravinantanakul, A., 2018. Paleomagnetic study on the Permian rocks of the Indochina Block and its implications for paleogeographic configuration and northward drifting of Cathaysialand in the PaleoTethys. J. Geophys. Res. Solid Earth 123, 4523-4538. https://doi.org/10.1029/ 2018JB015511.

Zachos, J.C., Breza, J.R., Wise, S.W., 1992. Early Oligocene ice-sheet expansion on Antarctica: stable isotope and sedimentological evidence from Kerguelen Plateau, southern Indian Ocean. Geology 20, 569-573.

Zeh, A., Brätz, H., 2004. Timing of Upper Carboniferous-Permian horst-basin formation and magmatism in the NW Thuringian Forest, central Germany: a review. Geol. Soc. Lond., Spec. Publ. 223 (1), 319-334.

Zhang, D., Huang, B., Zhao, J., Meert, J.G., Zhang, Y., Liang, Y., Bai, Q., Zhou, T., 2018. Permian paleogeography of the eastern CAOB: paleomagnetic constraints from volcanic rocks in central eastern Inner Mongolia, NE China. J. Geophys. Res. Solid Earth 123, 2559-2582. https://doi.org/10.1002/2018JB015614.

Ziegler, A.M., Eshel, G., Rees, P.M., Rothfus, T.A., Rowley, D.B., Sunderlin, D., 2003. Tracing the tropics across land and sea: Permian to present. Lethaia 36, 227-254.

Zijderveld, J.D.A., Hazeu, G.J.A., Nardin, M., Van der Voo, R., 1970. Shear in the Tethys and the Permian paleomagnetism in the southern Alps, including new results. Tectonophysics 10, 639-661. 